\title{
The Interactive Role of Hydrocarbon Seeps, Hydrothermal Vents and Intermediate Antarctic/Mediterranean Water Masses on the Distribution of Some Vulnerable Deep-Sea Habitats in Mid Latitude NE Atlantic Ocean
}

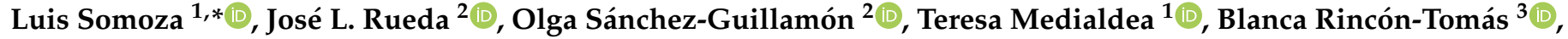 \\ Francisco J. González ${ }^{1}{ }^{\circledR}$, Desirée Palomino ${ }^{2}{ }^{\circledR}$, Pedro Madureira ${ }^{4}$, Enrique López-Pamo ${ }^{1}$, \\ Luis M. Fernández-Salas ${ }^{5}(\mathbb{D})$, Esther Santofimia ${ }^{1}$, Ricardo León ${ }^{1} \mathbb{D}$, Egidio Marino ${ }^{1} \mathbb{D}^{\mathbb{D}}$, \\ María del Carmen Fernández-Puga ${ }^{6}$ (D) and Juan T. Vázquez ${ }^{2}$ (D)
}

1 Marine Geology Division, Geological Survey of Spain (IGME), Ríos Rosas 23, 28003 Madrid, Spain; t.medialdea@igme.es (T.M.); fj.gonzalez@igme.es (F.J.G.); e.lopez@igme.es (E.L.-P.);

E.santofimia@igme.es (E.S.); r.leon@igme.es (R.L.); e.marino@igme.es (E.M.)

2 Instituto Español de Oceanografía (IEO), Centro Oceanográfico de Málaga, 29640 Málaga, Spain; jose.rueda@ieo.es (J.L.R.); olga.sanchez@ieo.es (O.S.-G.); desiree.palomino@ieo.es (D.P.); juantomas.vazquez@ieo.es (J.T.V.)

updates

Citation: Somoza, L.; Rueda, J.L.; Sánchez-Guillamón, O.; Medialdea, T.; Rincón-Tomás, B.; González, F.J.; Palomino, D.; Madureira, P.; López-Pamo, E.; Fernández-Salas, L.M.; et al. The Interactive Role of Hydrocarbon Seeps, Hydrothermal Vents and Intermediate

Antarctic/Mediterranean Water Masses on the Distribution of Some Vulnerable Deep-Sea Habitats in Mid Latitude NE Atlantic Ocean. Oceans 2021, 2, 351-385. https://doi.org/ 10.3390 /oceans 2020021

Academic Editor: Antonio Bode

Received: 13 December 2020

Accepted: 16 April 2021

Published: 26 April 2021

Publisher's Note: MDPI stays neutral with regard to jurisdictional claims in published maps and institutional affiliations.

Copyright: (c) 2021 by the authors. Licensee MDPI, Basel, Switzerland. This article is an open access article distributed under the terms and conditions of the Creative Commons Attribution (CC BY) license (https:// creativecommons.org/licenses/by/ $4.0 /)$.
3 Department of General Microbiology, Institute of Microbiology and Genetics, Georg-August University Göttingen, Wilhelmsplatz 1, 37073 Göttingen, Germany; b.rincontomas@gmail.com

4 Estrutura de Missão para a Extensão da Plataforma Continental (EMEPC), Rua Costa Pinto 165, 2770-047 Paço de Arcos, Portugal; pedro.madureira@emepc.mm.gov.pt

5 Instituto Español de Oceanografía (IEO), Centro Oceanográfico de Cádiz, Muelle de Levante (Puerto Pesquero), 11006 Cádiz, Spain; luismi.fernandez@ieo.es

6 Departamento de Ciencias de la Tierra, Facultad de Ciencias del Mar y Ambientales/INMAR, Universidad de Cádiz (UCA), Av. República Saharaui s/n, 11510 Cádiz, Spain; mcarmen.fernandez@uca.es

* Correspondence: 1.somoza@igme.es

Abstract: In this work, we integrate five case studies harboring vulnerable deep-sea benthic habitats in different geological settings from mid latitude NE Atlantic Ocean $\left(24-42^{\circ} \mathrm{N}\right)$. Data and images of specific deep-sea habitats were acquired with Remoted Operated Vehicle (ROV) sensors (temperature, salinity, potential density, $\mathrm{O}_{2}, \mathrm{CO}_{2}$, and $\mathrm{CH}_{4}$ ). Besides documenting some key vulnerable deep-sea habitats, this study shows that the distribution of some deep-sea coral aggregations (including scleractinians, gorgonians, and antipatharians), deep-sea sponge aggregations and other deep-sea habitats are influenced by water masses' properties. Our data support that the distribution of scleractinian reefs and aggregations of other deep-sea corals, from subtropical to north Atlantic could be dependent of the latitudinal extents of the Antarctic Intermediate Waters (AAIW) and the Mediterranean Outflow Waters (MOW). Otherwise, the distribution of some vulnerable deep-sea habitats is influenced, at the local scale, by active hydrocarbon seeps (Gulf of Cádiz) and hydrothermal vents (El Hierro, Canary Island). The co-occurrence of deep-sea corals and chemosynthesis-based communities has been identified in methane seeps of the Gulf of Cádiz. Extensive beds of living deep-sea mussels (Bathymodiolus mauritanicus) and other chemosymbiotic bivalves occur closely to deep-sea coral aggregations (e.g., gorgonians, black corals) that colonize methane-derived authigenic carbonates.

Keywords: seafloor mapping; vulnerable deep-sea habitats; deep-sea corals; chemosynthesis-based communities; vulnerable marine ecosystem; Atlantic Ocean

\section{Introduction}

Maintaining the sustainable functioning of the global biosphere requires protection of deep-sea ecosystems, particularly because they face major changes related to human and climate-induced impacts [1]. For an effective protection, an improvement in knowledge 
and research is essential, because the deep sea is truly the Earth's last frontier. Although oceans cover more than $70 \%$ of the Earth's surface, less than $0.0001 \%$ of the deep sea has been explored to date at a high resolution [2]. Seafloor bathymetry and habitat mapping are basic tools used to improve management in some areas of conservation importance and scientific interest [1]. High-resolution seabed mapping is essential for improving the current knowledge and understanding of deep-seafloor morphology, key geological processes (including sedimentary depositional and erosional processes), habitat distribution, and typology as well as availability of mineral deposits and energy resources, among other aspects. Seabed mapping is also valuable for more applied purposes such as the deployment of submarine cables and pipelines, detection of marine geohazards, development of early warning systems for volcanic eruptions, tsunamis, and earthquakes, prevention of pollution, management of fisheries, analysis of potential environmental impacts associated with deep-sea mining and for safer shipping. In summary, high-resolution seabed mapping studies provide data and information for researchers, contractors, industry, mining companies, regulators and Non-Governmental Organizations to manage and mitigate impacts on marine environments.

The main aim of the present study is to integrate bathymetry and seafloor geomorphology, water masses properties, and the distribution of vulnerable deep-sea habitats (and their associated biota) along the southernmost NE Atlantic Ocean. These vulnerable deep-sea habitats include those conformed by deep-sea corals (in this study including deep-sea scleractinians, stony octocorals, bamboo corals, soft corals, gorgonians. and antipatharians), sea-pens, sponges and chemosynthesis-based communities. This integration has been applied to five case studies located between $24^{\circ}$ and $42^{\circ} \mathrm{N}$ at $90-2500 \mathrm{~m}$ below sea level (mbsl) including: (1) Deep-sea scleractinian reefs (dominated by Desmophyllum pertusum) still thriving on the Galicia Bank; (2) Chemosynthesis-based communities of hydrocarbon seeps in the Gulf of Cádiz colonized by sponges, gorgonians, scleractinians, and black corals; (3) Deep-sea stony octocoral aggregations occurring on volcanic submarine ridges located along the Passage of Lanzarote; (4) New habitats formed after the Tagoro submarine eruption in 2011-2012; and (5) Aggregations of scleractinians, antipatharians, gorgonians, bamboo corals, and sponges on ferromanganese crusts of seamounts of the subtropical Canary Island Seamount Province (CISP). These five case study areas have been mapped in detail with MBES and ground truthed by means of ROV surveys and/or coring/dredging samples. The water mass properties for each specific habitat were obtained with in-situ ROV-mounted CTD (Conductivity-Temperature-Depth sound) and Niskin bottles. The comparison between vulnerable deep-sea habitats of these case studies allows us to analyze: (i) the potential relationship between water mass properties (salinity, oxygen, potential density, oxygen and methane concentration) for each specific habitat as a function of water depth and latitude, (ii) the influence of methane seeps on the distribution of some of these deep-sea habitats; and (iii) the influence of abrupt submarine eruptions and low-temperature hydrothermal vents in the Macaronesia volcanic archipelagos.

\section{Geological and Oceanographic Settings}

The five case-study areas include important types of world-wide recognized geomorphological seabed features such as banks, mud volcanoes (MVs), coral mounds and reefs, oceanic passages, contourite drifts, volcanic ridges, salt domes, seamounts, and submarine volcanoes $[3,4]$.

\subsection{The Galicia Bank}

The first case study concerns banks and reefs of colonial scleractinians (mainly D. pertusum) located at 700-1800 mbsl on the Galicia Bank, NE Atlantic (Figures 1 and 2A). The Galicia Bank, with an area of $2117 \mathrm{~km}^{2}$ (Figure 3A), constitutes the main structural high located on the NW Iberian continental margin, $200 \mathrm{~km}$ west off the Galician coast. The summit of the bank yields a contourite depositional system associated with the Mediterranean Outflow Water (MOW) and consists of erosive furrows and depositional bottom-current 
features such as drift and sediment wave fields [5,6]. Large pavement-like plates composed of phosphorite slabs and ferromanganese crusts dominate the top of the Galicia Bank [7]. Several water masses have been recognized to influence key processes of the Galicia Bank. Water masses above $500 \mathrm{mbsl}$ are dominated by the Eastern North Atlantic Central Water current (ENACW). Below the minimum salinity located near $500 \mathrm{mbsl}$, the ENACW gradually mixes with the MOW reaching a peak in salinity values (36.1-36.5 psu) at approximately $1000 \mathrm{mbsl}$. The MOW, in this area, is characterized by an increase of the salinity values at 800 and $1200 \mathrm{mbsl}$ and acts as a contour current above and around the Galicia Bank reaching velocities of $5-10 \mathrm{~cm} \mathrm{~s}^{-1}$ [8].

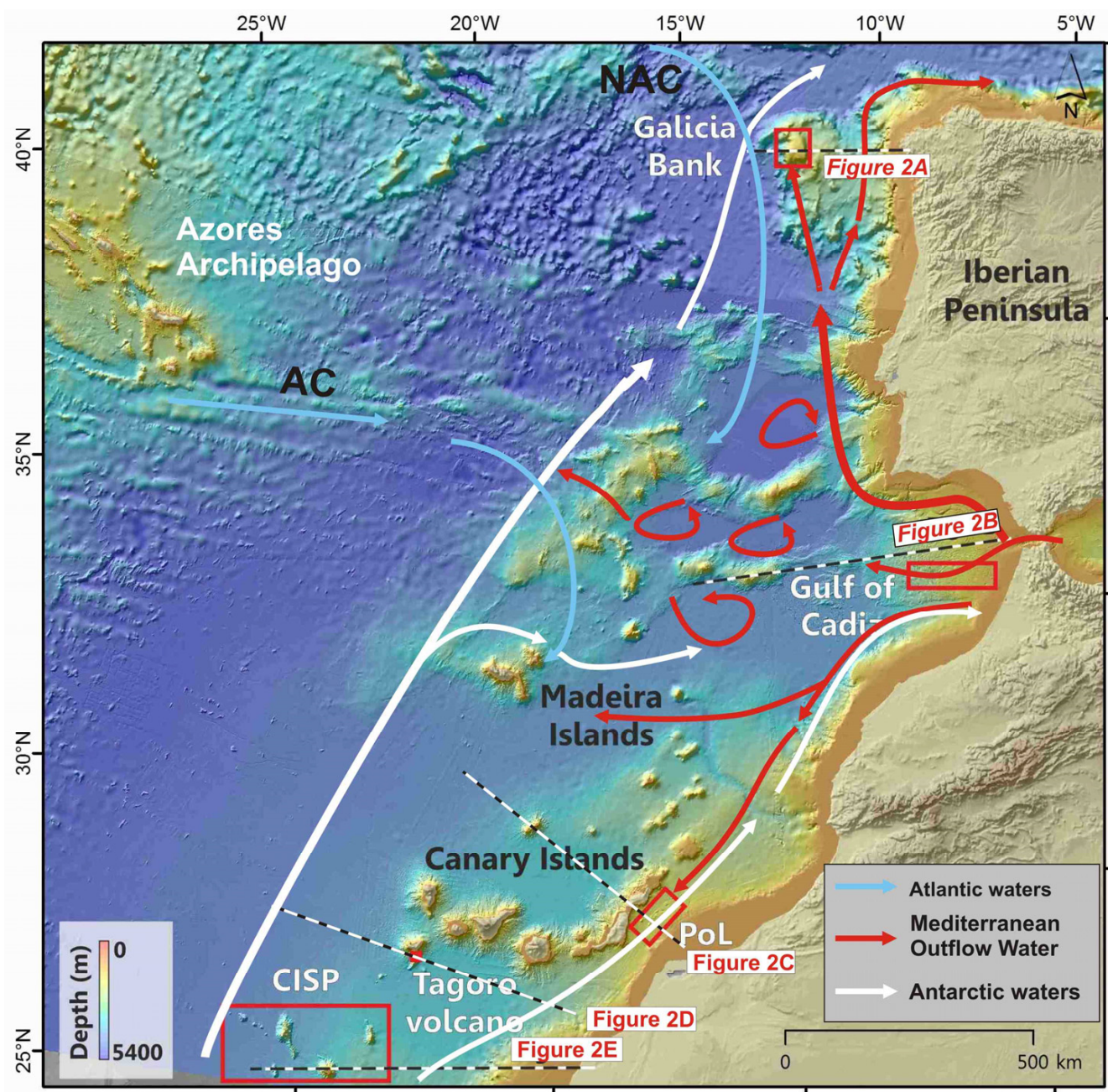

Figure 1. Location of case studies areas along the North East and Central Atlantic Ocean and schematic oceanographic circulation affecting the cases studies. CISP: Canary Islands Seamount Province; PoL: Passage of Lanzarote. Main currents from [8-12] are labelled as: North Atlantic Current (NAC), Azores Current (AC). Regional bathymetric map extracted from the EMODnet Project (http:/ / www.emodnet.eu/bathymetry, accessed on 1 December 2020).

\subsection{Gulf of Cádiz and Moroccan Atlantic Margin}

The second case study refers to chemosynthesis-based habitats and other vulnerable deep-sea habitats (aggregations of sponges, gorgonians, antipatharians, among others) in mud volcanoes (MVs) located in the Moroccan Atlantic margin of the Gulf of Cádiz (GoC) between $34^{\circ}$ and $35^{\circ} \mathrm{N}$ (Figures 1 and $2 \mathrm{~B}$ ). In the GoC, extensive geophysical research and seabed sampling have resulted in the discovery of $84 \mathrm{MVs}$ and MVs-mud diapir complexes since 2000 [13-21]. Mud volcanism in the GoC is primarily associated with high concentrations of thermogenically-derived methane [22]. Different sources have been invoked for 
mud volcanism in the GoC: Pliocene and Late Miocene shales, the so-called Allochthonous Unit of the GoC and even deeper sources of Mesozoic age [23,24]. Carbonates and ferromanganese rocks such as methane-derived authigenic carbonates (MDACs) $[25,26]$ formed by microbial-mediated anaerobic oxidation of methane (AOM) [27] and Fe-rich nodules formed by later exhumation, oxidation and diagenesis of buried AOM products [28]. Three types of intermediate water masses are currently considered in the case study of the GoC (Figure 1): the Eastern North Atlantic Central Water current (ENACW), the Mediterranean Outflow Water (MOW), the North Atlantic Deep Water current (NADW), and the Subarctic Intermediate Water current (SAIW).

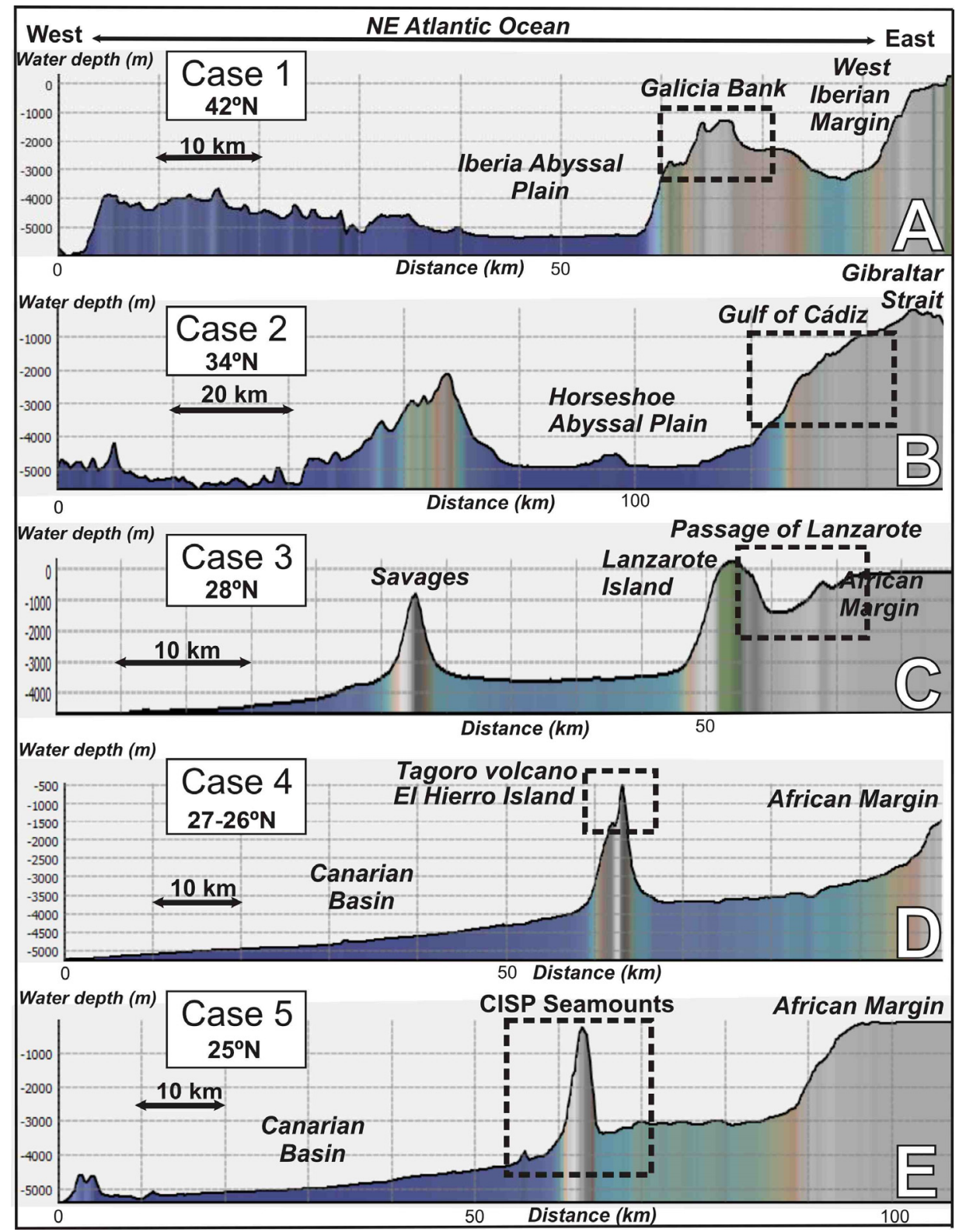

Figure 2. E-W regional bathymetric profiles along the North East and Central Atlantic Ocean showing the morpho-structural context and water depth distribution of the studied areas. (A) Galician margin; (B) Gulf of Cádiz; (C) Passage of Lanzarote (PoL), (D) Tagoro volcano, El Hierro Island, and (E) Canary Island Seamount Province (CISP). Profiles extracted from bathymetry of the Global Multi-Resolution Topography (GMRT) synthesis data set [29]. See Figure 1 for location. 

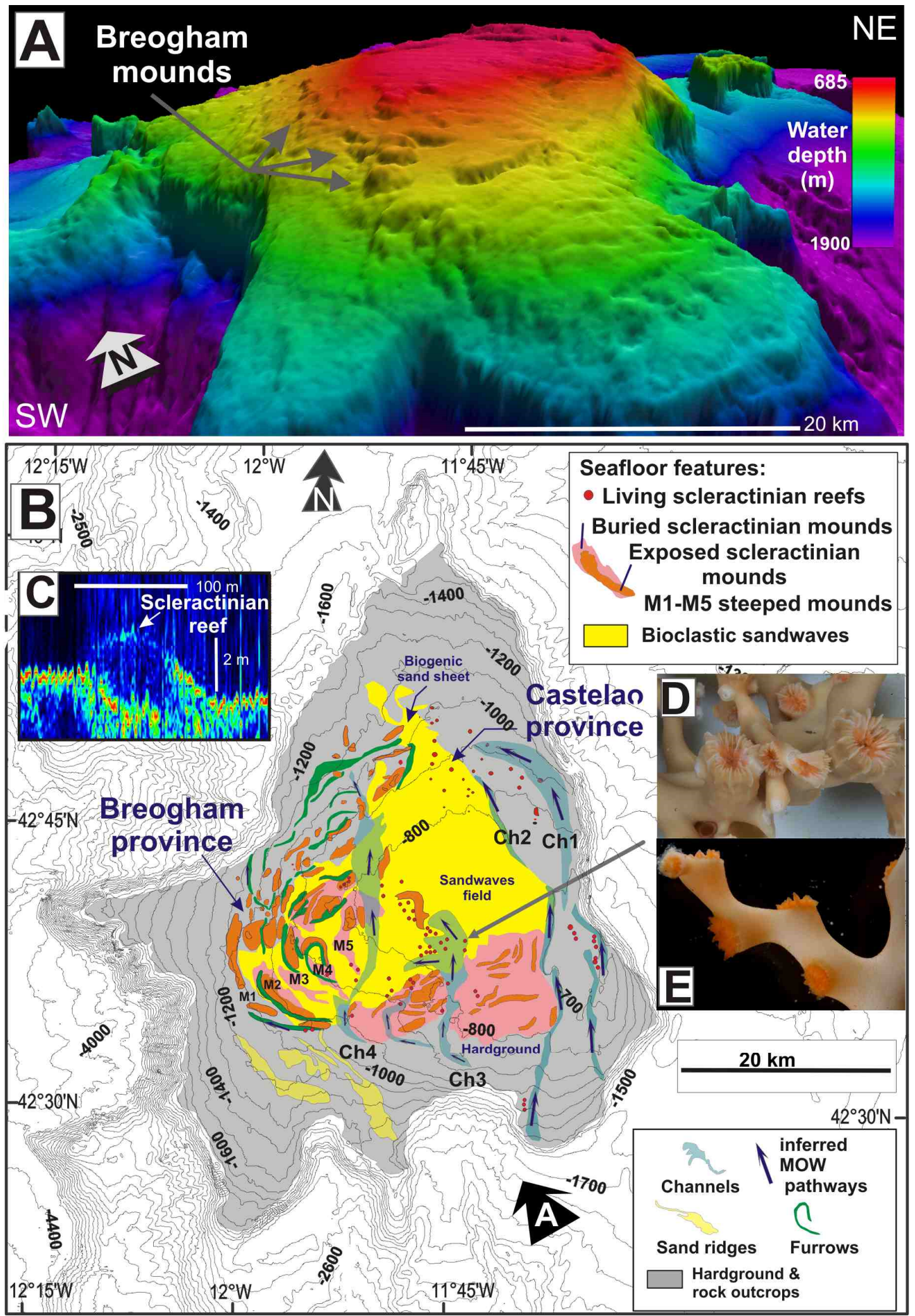

Figure 3. Seabed distribution of scleractinian reefs and mounds (M) in the Galicia Bank: (A) 3D shaded relief model using multibeam bathymetry data; Sunlight from the NW; (B) Morphological map including morpho-sedimentary features and scleractinian reefs identified with multibeam and backscatter data; (C) Ultra high-resolution sub-bottom profile crossing scleractinian reefs were (D,E) living Desmophyllum pertusum and Madrepora oculata appear. 


\subsection{The Passage of Lanzarote-Canary Islands-NW African Margin}

The third case study focuses on the Passage of Lanzarote (PoL), between the Canary Islands (Fuerteventura-Lanzarote Islands) and the West African Continental Margin (Figure 1). The bathymetric profile transverse to the PoL is asymmetrical with the passage narrowing towards the south, showing a steeper western flank (Figure 2C). The PoL has maximum water depths at its center, ranging between 1240 and 1460 mbsl (Figures 1 and 2C). Two groups of seafloor morphologies stand out in the submarine relief of this passage [30,31]: (a) seamounts and hills related to volcanic ridges and salt domes and (b) bottom current-related features. Three main types of water masses have been identified circulating through the PoL (Figure 1) $[10,32,33]$ : The upper thermocline North Atlantic Central Water current (NACW), which spans from the surface to the neutral density $\left(\Upsilon_{n}\right)$ value of $27.3 \mathrm{~kg} / \mathrm{m}^{3}$ (approximately $600 \mathrm{mbsl}$ ); and the Antarctic Intermediate Water current (AAIW) reflected by a clear S minimum and found below the NACW (roughly 700-1600 mbsl).The AAIW is well identified along the African continental margin with a predominantly northward flow which often exceed $0.02 \mathrm{~m} \mathrm{~s}^{-1}$, appearing particularly intense (up to $0.06 \mathrm{~m} \mathrm{~s}^{-1}$ near the bottom) during the summer seasons [33]; the third, the Mediterranean Modified Water current (MW), a modified branch of the MOW identified in individual profiles by high-salinity peaks flowing southwards between $900 \mathrm{mbsl}$ to the bottom with a mean southward flow of $-0.05 \mathrm{~Sv}$ [33]. In winter and spring, the formation of active meddies (Mediterranean Outflow Water eddies) have been reported at the north of the PoL between $12^{\circ} \mathrm{W}$ and $15^{\circ} \mathrm{W}$ [33]. The occurrence of submarine mounds along this deep-water passage promotes the intensification of the turbulence at the interface between the AAIW and MW bottom currents [31,32].

\subsection{El Hierro Island, Canary Islands}

The fourth case study highlights the natural successional changes in newly formed volcanic substrates and habitats related to recent submarine eruptions that occurred in 2011-2012, south of El Hierro Island, Canary Islands (Figures 1 and 2D). Dead fish and patches of pale colored water at the sea surface indicated the onset of a submarine eruption on 10 October 2011 at $5 \mathrm{~km}$ distance from the town of La Restinga. The El Hierro eruption continued during late February, when seismicity decreased drastically until 6 March 2012. As a result of this shallow submarine eruption, a new submarine volcano grew from 375 to 89 mbsl [34]. Since 2016, the new volcano appears on the official hydrographic charts as "Tagoro" (meaning "stone circle for meeting place" in the aboriginal language of Canary Islands). The eruption consisted of two main phases of edifice construction intercalated with collapse events. After the cessation of the volcanic eruption, emissions of large quantities of iron and carbon dioxide from submarine hydrothermal vents were reported $[35,36]$. Several oceanographic expeditions were carried out during and after the eruption of the Tagoro volcano (Supplementary Table S1). These expeditions have allowed the identification of the development of new habitats after the eruption, associated with the emission of large quantities of iron and carbon dioxide from hydrothermal submarine vents.

\subsection{The Canary Island Seamounts $\left(23^{\circ} 48^{\prime} \mathrm{N}-26^{\circ} 30^{\prime} \mathrm{N}\right)$}

The fifth case study comprises the southern seamounts of the Canary Island Seamount Province (CISP), located southwest of the Canary Islands and $100 \mathrm{~km}$ west off the African coast (Figures 1 and 2E). The CISP is composed of more than 100 seamounts and submarine hills rising from $\sim 5000$ to $200 \mathrm{mbsl}$ [37]. The CISP extends from the Lars-Essauira seamount, approximately $400 \mathrm{~km}$ from the north of Lanzarote $\left(32.7^{\circ} \mathrm{N}, 13.2^{\circ} \mathrm{W}\right)$ to the Tropic seamount, $500 \mathrm{~km}$ at the southwest of the archipelago $\left(23.8^{\circ} \mathrm{N}, 20.7^{\circ} \mathrm{W}\right)$. This case study focuses on the southern CISP area which is characterized by the presence of several large seamounts, including The Paps, Echo, Drago and Tropic, rising from $\sim 5000 \mathrm{~m}$ to 200 mbsl (Figures 1 and 2E). These are the oldest seamounts of the CISP, dated between 91 and $119 \mathrm{Ma}$ [38]. The seabed of these seamounts is mainly composed of ferromanganese crusts and nodules growing on basalt-sedimentary rock substrates containing high average 
amounts of Fe (23.5 wt\%), Mn (16.1 wt\%), and trace elements like Co (4700 $\mu \mathrm{g} / \mathrm{g}), \mathrm{Ni}$ $(2800 \mu \mathrm{g} / \mathrm{g}), \mathrm{V}(2400 \mu \mathrm{g} / \mathrm{g})$, and $\mathrm{Pb}(1600 \mu \mathrm{g} / \mathrm{g})$ [39-41]. The oldest age of initiation of the ferromanganese crusts growth was estimated at $90 \mathrm{Ma}$ [40]. The CISP seamounts are located beneath the northern end of the Oxygen Minimum Zone (OMZ), which extends from 100 to $700 \mathrm{mbsl}$, from near the equator to $25^{\circ} \mathrm{N}$ [42]. The core of the $\mathrm{OMZ}$ is located at $400-500 \mathrm{mbsl}$, reaching very low oxygen values $(<50 \mu \mathrm{mol} / \mathrm{kg})$. The dissolved oxygen is also depleted by the high biological productivity in proximity to the Canary Islands due to upwelling and nutrient-rich currents [42]. At intermediate depths, the low oxygen waters are ventilated by the ENACW and by the South Atlantic Central Water current (SACW) above $700 \mathrm{mbsl}$ and by the AAIW at $1000 \mathrm{mbsl}$. The North Atlantic Deep-Water current (NADW) flows at depths below $1500 \mathrm{mbsl}$ and the Antarctic Bottom Water current (AABW) flows below 4000 mbsl [33] (Figure 1). These deep bottom currents accelerate around the seamounts, increasing the supply of nutrients related to high inputs of Fe and P sourced from the Sahara dust [39].

\section{Materials and Methods}

Mapping the seafloor and its specific habitats (and Vulnerable Marine Ecosystems, VMEs) at regional scale requires interdisciplinary research teams using a wide suite of surveying techniques. Data of this work were collected mainly during the SUBVENT-2 cruise aboard RV Sarmiento de Gamboa [43]. Other data included in this work were collected during a set of extensive scientific expeditions listed in the Supplementary Table S1. A summary of the cruise details for each of the five case studies including data sets collected, MBES systems and ground truthing data sets are listed in Supplementary Table S1.

The multibeam bathymetry echosounder (MBES) Atlas DS $1 \times 1$ on board the RV Sarmiento de Gamboa has been used for seabed mapping of the distinct habitats and to plan ROV tracks (see Supplementary Table S1 for further details on MBES systems). MBES data were processed using CARIS HIPS\&SIPSTM version 9 software (Teledyne CARIS, Frederiction, NB, Canada). The MBES data were used to generate Digital Terrain Models (DTM) at spatial resolutions of 30-50 m (depending on water depth). The multi-resolution DTM was used to produce regional sun-shaded image renders, perspective views and to extract margin-wide bathymetric profiles using Fledermaus ${ }^{\mathrm{TM}}$ version 7 software (QPS, Porstmouth, NH, USA) to interpret the submarine landscapes. It was also used to generate derivative products such as slope angle maps by means of ArcGISTM desktop v. 12.4.

The ATLAS P-35 used aboard the RV Sarmiento de Gamboa is a parasound echosounder with two frequencies: a Primary High Frequency (PHF) at $20 \mathrm{kHz}$ and a Secondary Low Frequency (SLF) at $4.5 \mathrm{kHz}$. PHF was used to record anomalies within the water column, whereas SLF was used as a sub-bottom profiler to record sediment/rock features (Supplementary Table S1).

Submersible observations and sampling of the seafloor were carried out with the ROV Luso (from Estructura de Missão para a Extensão da Plataforma Continental, Portugal), equipped with a high definition video camera Argus HD-SDI Camera (ARGUS Remote Systems AS, Laksevag, Norway), two robotic manipulators to recover biological and geological samples, a CTD (conductivity, temperature, and depth measurements) with fluorescence, turbidity and $\mathrm{CO}_{2-}, \mathrm{CH}_{4}$ - and $\mathrm{O}_{2}$ - sensors, and four Niskin bottles for water sampling (Supplementary Table S1). Water samples (two replicates of $20 \mathrm{~mL}$ ) were taken for methane determination using a gas chromatograph in cold seep areas. Rock-mineralization samples and associated biota were taken by means of conventional rectangular benthic dredges $(0.8 \mathrm{~m}$ in width by $0.6 \mathrm{~m}$ in height) towed on the seafloor during 10 to $20 \mathrm{~min}$ at 1 knot speed. ROV tracks were planned after analysis and interpretation of previous MBES mapping (DTM of the bathymetry) and backscatter models. Gravity cores with a maximum length of $300 \mathrm{~cm}$ were taken on the summits and/or slopes of the mud volcanoes. The cores were photographed and a visual lithostratigraphic description was made in each case.

Regional oceanographic data were extracted from Conductivity-Temperature-Depth (CTD) of the World Ocean Database 2018 [44] of the National Centers for Environmental 
Information (NOAA) (http:/ / www.nodc.noaa.gov/OC5/indprod.html, accessed on 1 December 2020). We use Ocean Data View 4.0 software (Alfred-Wegener-Institut HelmholtzZentrum für Polar- und Meeresforschung, Bremerhaven, Germany) [45] for displaying regional oceanographic variables.

\section{Results}

\subsection{Description of Vulnerable Deep-Sea Habitats of Each Case Study}

In this section, the morphology and the type of habitats and communities in the five case studies from the north Atlantic $\left(42^{\circ} \mathrm{N}\right)$ to subtropical Atlantic $\left(23^{\circ} \mathrm{N}\right)$ have been described. Full details of substrate types, water depth ranges, geomorphology, habitat types, and the associated biota for each specific site are listed in the Supplementary Table S2.

\subsubsection{Case Study 1: Scleractinian Reefs in the Galicia Bank $\left(42^{\circ} 15^{\prime} \mathrm{N}-42^{\circ} 55^{\prime} \mathrm{N}\right)$}

A large number of live scleractinian colonies of Desmophyllum pertusum (previously named as Lophelia pertusa) and Madrepora oculata have been identified conforming reefs on the summit and flanks of the Galicia Bank at water depths between 620 and 1175 mbsl (Figure 3). The distribution of these scleractinian reefs has been mapped by means of MBES backscatter mosaic images, ultra-high resolution and high-resolution multichannel seismic reflection data and seabed sampling (Figure 3). A complete sequence of stepped elongated reefs (M1 to M5 in Figure 3), known as Breogham mounds and characterized by high backscatter strengths with a seabed expression, were identified on multibeam bathymetry along the western flank of the Galicia Bank (Figure 3A,B).

These semi-buried reefs display heights up to $70 \mathrm{~m}$ and widths of $450 \mathrm{~m}$ and are lined up in along-slope trending ridges from 826 to $1126 \mathrm{mbsl}$. Furthermore, on the top and at the eastern flank of the bank, a series of mini-reefs, 2-4 high and 80-100 m wide appear on a flat erosion surface at 780-750 mbsl. Mini reefs with living scleractinian colonies appear as acoustically transparent domes in very high-resolution sub-bottom profiles (Figure 3C). We interpret their low acoustic response $\left(\sim 1520 \mathrm{~ms}^{-1}\right)$ close to values for the water column, as due to the high contents of seawater within their skeletons, as well as the open space created by the skeletal growth patterns. Samples of these still thriving scleractinian reefs yielded living D. pertusum and M. oculata (Figure 3D,E). In contrast, older and semi-buried scleractinian reefs were partially cemented forming elongated mounds along the flanks of the bank, being characterized by higher backscatter responses [46]. In some cases, scleractinians, mollusc monoplacophora (Laevipilina rolani), and bryozoans [47] occurred on encrusted phosphorites and ferromanganese nodules substrates at 750-1400 mbsl in the southeast Galicia Bank.

4.1.2. Case Study 2: Chemosynthesis-Based Communities and Other Vulnerable Deep-Sea Habitats on Hydrocarbon Seeps of the Gulf of Cádiz $\left(34^{\circ} \mathrm{N}-35^{\circ} \mathrm{N}\right)$

Six MVs located between 350 and 3000 mbsl (Mercator, Algacel, Yuma, Madrid, Las Negras, and Bonjardim), were explored with the ROV "Luso" during the oceanographic expedition SUBVENT-2 [43] (Location shown in Figure 4A). Chemosynthesis-based communities and high methane concentrations were detected in these explored MVs. Reduced grey mud breccias were recovered by gravity cores in all cases, when testing the nature of extrusion of these cones. 

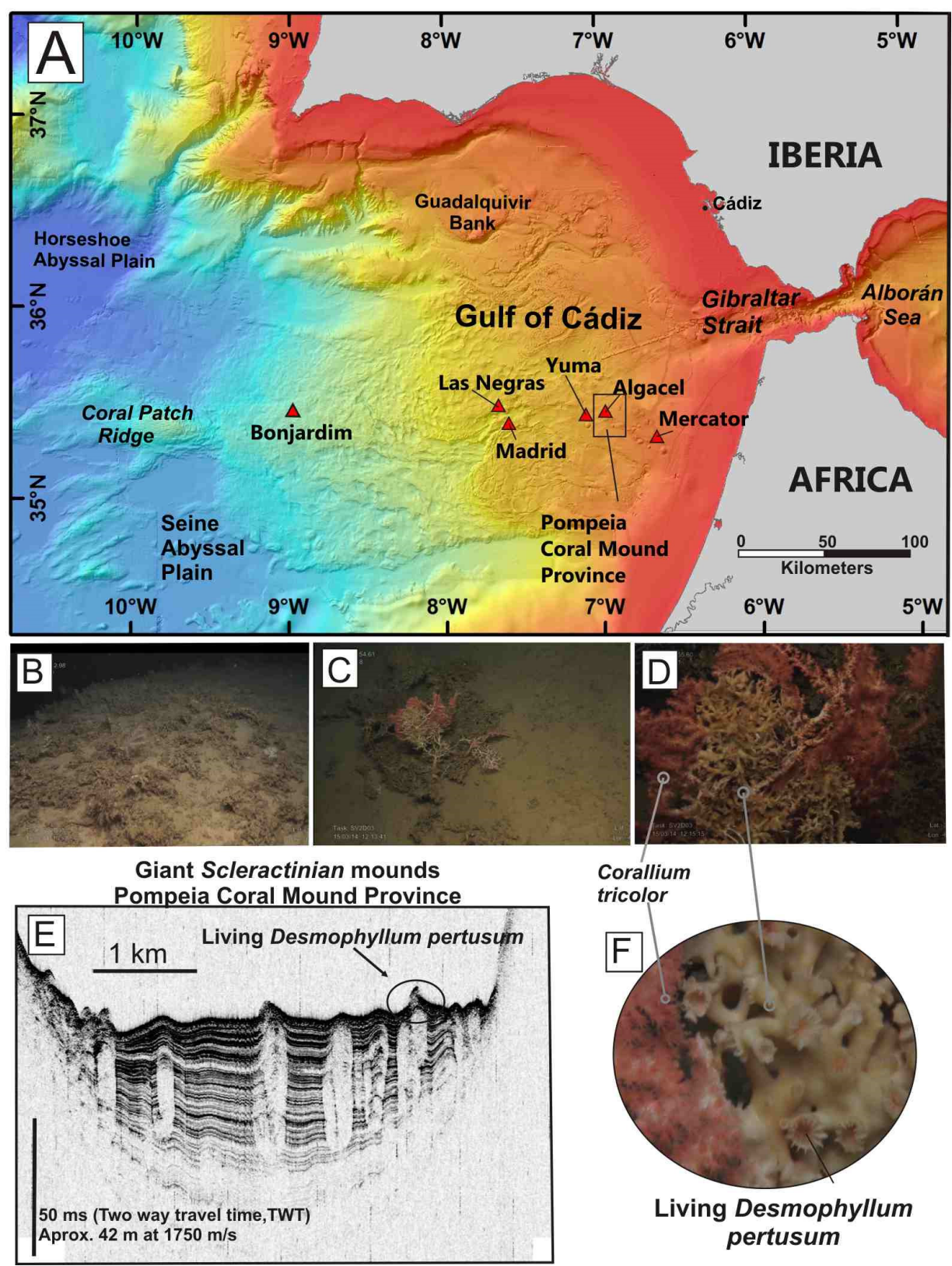

Figure 4. (A) Location of mud volcanoes explored in the present study in the Gulf of Cádiz along $35.5^{\circ} \mathrm{N}$ and the Pompeia Coral Mound Province. (B) Dead scleractinian skeletons at the top of the mounds. (C,D,F) Stony octocorals (Corallium tricolor) overlying live and dead colonies of Desmophyllum pertusum on mounds at the Pompeia Coral Province; (E) Ultrahigh-resolution sub-bottom profile showing giant coral mounds (transparent bodies) up to $42 \mathrm{~m}$ in height beneath the dead scleractinian reefs at the Pompeia Coral Mound Province.

The type of habitats identified in these MVs can be resumed into seven types (See details in Supplementary Table S2):

(1) Active methane seeps with chemosynthesis-based communities.

(2) Non-active pockmarks colonized by Cerianthids

(3) Aggregations of sponges, gorgonians, black corals, soft corals and bamboo corals colonizing methane-derived authigenic carbonates (MDACs)

(4) Hexactinellid sponge aggregations on muddy sediments and coral graveyards.

(5) Desmosponges aggregations on muddy sediments.

(6) Sea-pen (pennatulaceans) communities on micro-mounds muddy sediments. 
(7) Graveyards of scleractinians colonized by stony octocorals.

Chemosynthesis-based communities were mainly detected on the summits and sometimes on the flanks (e.g., Algacel MV), of the surveyed MVs (Figure 5) and contained different types of taxa and rates of methane flux. Regarding this, in MVs with high methane fluxes such as Algacel MV (methane concentrations up to $97.60 \mathrm{nM}$ ) (Figure 5A-C), harbored living deep-sea mussel Bathymodiolus mauritanicus beds, containing both small- and large-size specimens were found. These beds formed large linear and circular mussel clumps (up to $10 \mathrm{~m}$ in diameter) surrounding emissions of intermittent gas bubbling with methane concentrations of $97.60 \mathrm{nM}$ (Figure 6A-E).
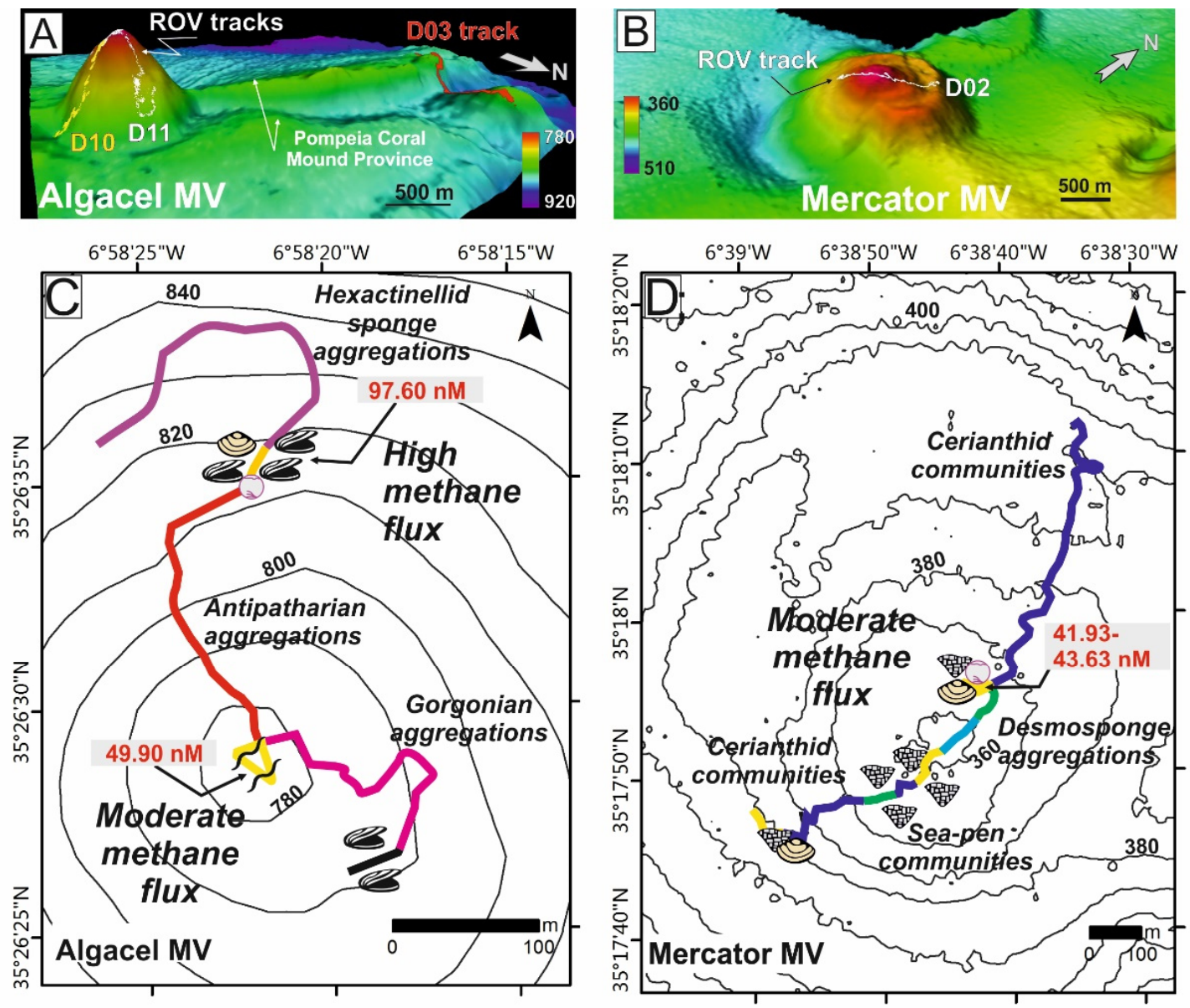

Qe) Chemosymbiotic bivalves Pockmarks Siboglinids Bacterial mats

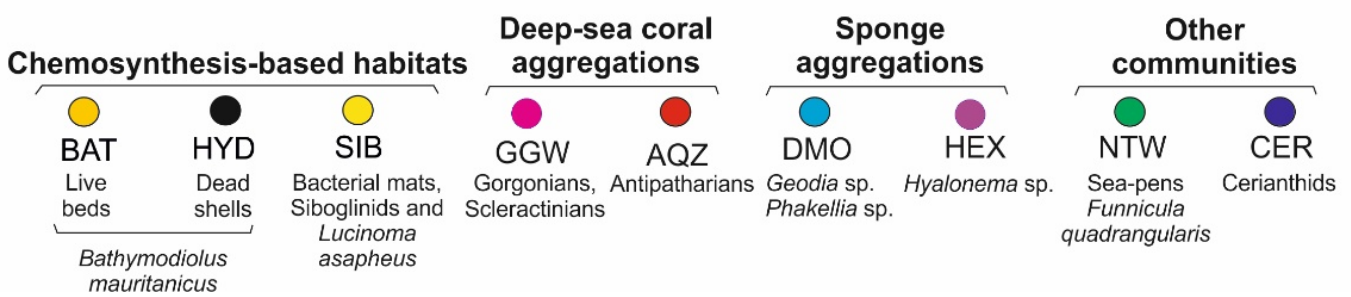

Figure 5. Vulnerable deep-sea habitats in mud volcanoes (MVs) of the Moroccan margin (Gulf of Cádiz). (A,B) 3D models of the Algacel and Mercator MVs as well as the Northern Pompeia Coral Ridge at the Pompeia Coral Mound Province, where ROV dives were carried out. Distribution of deep-sea habitats and organisms across (C) Algacel and (D) Mercator MVs. Methane concentrations are displayed in red letters. Location of MVs in Figure 4A. See further explanation in the text. 


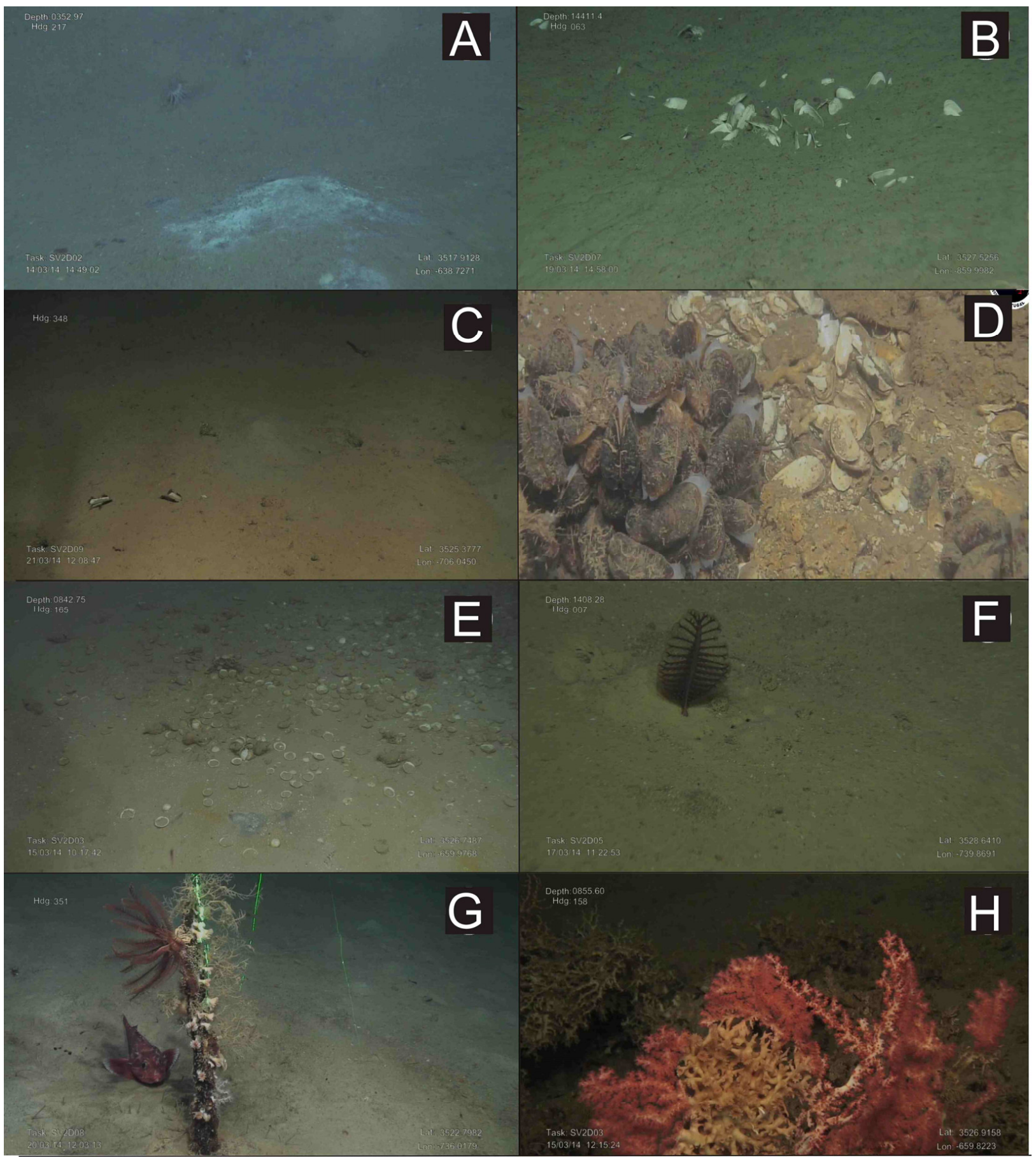

Figure 6. Underwater images obtained with the ROV "Luso"during the SUBVENT-2 expedition in mud volcanoes (MVs) of the Moroccan margin. (A): Beggiatoa-like bacterial mats and two cerianthids at the summit of the Mercator MV; (B): Accumulation of shells of the chemosymbiotic bivalve Isorropodon megadesmus on muddy substrates at the summit of the Bonjardim MV; (C): Shells of the chemosymbiotic bivalve Acharax gadirae at the summit of the Yuma MV; (D): Beds of the living chemosymbiotic Bathymodiolus mauritanicus in the Algacel MV; (E): Extensive graveyards of the chemosymbiotic bivalve Lucinoma asapheus at the Northern Pompeia Coral Ridge (Pompeia Coral Mound Province); (F): Sea-pen (Pennatula sp.) on muddy sediments at the Las Negras MV; (G): An iron bar of anthropogenic origin colonized by small gorgonians, solitary corals (Desmophyllum dianthus) and crinoids at the Yuma MV; $(\mathbf{H})$ : Living scleractinians $(D$. pertusum) and stony octocorals (Corallium) colonizing dead scleractinian skeletons in the Pompeia Coral Mound Province.

In MVs with moderate methane fluxes (30-50 nM), including the Mercator, Las Negras, and Madrid MVs, living chemosymbiotic bivalves such as A. gadirae and Solemy aelarraichen- 
sis occurred with high densities of shells of Thyasira vulcolutre, S. elarraichensis, Isorropodon megadesmus and B. mauritanicus. Dense populations of frenulate polychaetes (Siboglinum sp.) also occured in some of these MVs with moderate methane fluxes (Figure 5B-D). Sulfur-oxidizing bacterial (SOB) mats forming macroscopically visible cohesive white patches of 10-30 $\mathrm{cm}$ in diameter were also detected (Figure 6A).

In MVs with low methane fluxes such as the Bonjardim MV (20.18-28.12 nM), the past occurrence of chemosynthesis-based communities is revealed by abundant shells of the chemosymbiotic bivalve I. megadesmus (Figure 6B).

Crater-like pockmarks identified on the MVs seafloor, 1-3 $\mathrm{m}$ in width, provide evidence of former blow-outs that are nowadays colonized with non-chemosynthetic organisms such as sea-pens (Funiculina quadrangularis), cerianthids, and annelids (Hyalinoecia tubicola).

Aggregations of gorgonians (Swiftia), antipatharians (Bathypathes, Leiopathes, Stichopathes), bamboo corals (Chelidonisis), and scleractinians (D. pertusum) colonize MDACs blocks (up to $1 \mathrm{~m}$ ) formed by anaerobic oxidation of methane (AOM) on the summit and flanks of the MVs with high rates of diffuse methane release such as the Algacel MV (Figure 5C). Otherwise, large desmosponges aggregations (Geodia sp., Phakellia sp.) colonized blocks of MDACs formed on the summit and flanks of MVs with lower methane fluxes (Figure 5D). Along the flanks of some MVs, muddy sediments covered with scattered patches of dead scleractinians (coral rubble) and small MDAC gravels are colonized by hexactinellid sponges (Pheronema, Hyalonema) and gorgonians (Radicipes on soft substrates and Swiftia on MDAC gravels).

Other non-chemosymbiotic deep-sea species such as sea-pens (Kophobelemnon sp., Pennatula, Anthoptilum), cerianthids, holothurians, and decapod species of commercial interest (Aristeomorpha foliacea, Plesiopenaeus edwardsianus) were also detected on the soft substrates of MVs (Figure 6F).

Ridges and mounds with abundant scleractinian skeletons (mainly D. pertusum and M. oculata), but with scarce living D. pertusum colonies and stony octocoral colonies (e.g., C. tricolor) were detected westwards of the Algacel MV in the Pompeia Coral Mound Province (Figure 4). Patches of chemosymbiotic bivalve shells (mainly L. asapheus with some Thyasiravulcolutre), and scattered bacterial mats (Beggiatoa-like sulfur oxidizers) were also detected (Figure $6 \mathrm{E}, \mathrm{H}$ ). Ultra-high-resolution profiles below the scleractinian skeletons show that they represent the top of giant buried mounds that reach up to $42 \mathrm{~m}$ in height (equivalent to $50 \mathrm{~ms}$ two-way travel time, TWT, assuming an average sonic velocity of $1750 \mathrm{~m} \mathrm{~s}^{-1}$ for recent sediments) (Figure 4E). The potential causes of the regression of these giant coral mounds in the GoC will be considered in the Section 5. Methane concentrations on the seafloor of the ridge at the Pompeia Coral Mound Province range from 41.93 to $43.24 \mathrm{nM}$, indicating the occurrence of moderate seepage. The E-W orientation of these ridges at the westward side of the Algacel MV (Figure 5A) points to the influence of strong bottom currents causing strong turbulences on their lee face.

4.1.3. Case Study 3: Stony Octocorals, Gorgonians, Soft-Corals and Sponge Aggregations along the Passage of Lanzarote $\left(28^{\circ} 30^{\prime} \mathrm{N}-29^{\circ} \mathrm{N}\right)$

The third case study focuses on the hard-substrate and sedimentary habitats of the Passage of Lanzarote (PoL) located between the Canary Islands (Fuerteventura-Lanzarote ridge) and the West African Continental margin (Figure 1). Three main types of morphologies can be described based on the bathymetric map along the PoL: Elongated mounds (M), volcanic ridges, volcanic cones and sub-circular sea-floor depressions (Figure 7) 


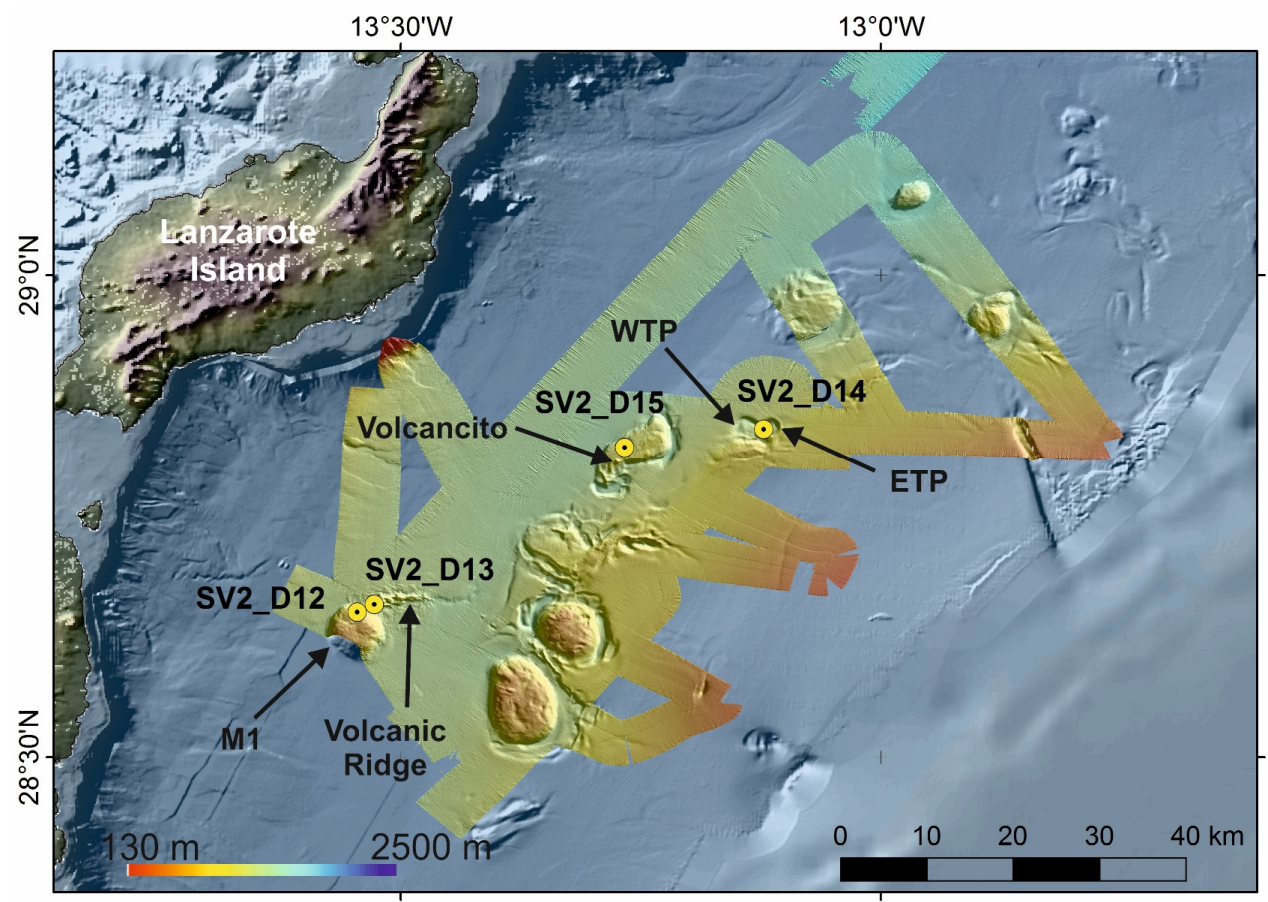

Figure 7. Bathymetric map obtained along the SUBVENT-2 expedition on board RV Sarmiento de Gamboa. The main characteristics of the seafloor such as sub-circular domes, volcanic ridges, marginal channels and circular to elongated depressions are highlighted. Locations of dives (from SV2_D12 to SV2_D15) are also shown as circles. M1: Dome; WTP: Western Twin Pool; ETP: Eastern Twin Pool.

Mounds are cylindrical or sub-rounded highs, $2-10 \mathrm{~km}$ in diameter with flat summits (e.g., M1 in Figure 7). The base of the mounds along the PoL ranges between 1225 and $1530 \mathrm{mbsl}$ and their summits between 828 and $1336 \mathrm{mbsl}$. The volcanic ridges are $6 \mathrm{~km}$ long, $150 \mathrm{~m}$ high, E-W trending linear ridges detached from the mounds (e.g., the Volcanic Ridge in Figure 7). Volcanic cones are single structures 15-70 $\mathrm{m}$ height and 350-700 $\mathrm{m}$ in diameter crossing the flat summits of the mounds (e.g., the Volcancito in Figure 7). Six circular or slightly elliptical depressions have also been identified in the continental slope of the West African continental margin at the PoL [48]. They are located between 750 and $1415 \mathrm{mbsl}$, and their reliefs vary between 40 and $240 \mathrm{~m}$. The length and width of their axes range from 2 and $4.5 \mathrm{~km}$ to 2 and $3.3 \mathrm{~km}$, respectively. The surveyed deep depressions have named as the Twin Pools [48] (Western and Eastern Twin Pool, WTP and ETP respectively in Figure 7). Otherwise, the basin morphology of the PoL is dominated by channels and moats related to the interaction of the strong bottom currents with the seabed (Figure 7). Therefore, a NE-SW central channel $100 \mathrm{~km}$ in length and $1-5 \mathrm{~km}$ in width is located at $1290 \mathrm{mbsl}$ in the central sector and deepens toward the NE $(1460 \mathrm{mbsl})$ and towards the SW (1320 mbsl). Rimmed depressions around the mounds classified as moats are $0.5-2 \mathrm{~km}$ widths incising to $180 \mathrm{~m}$ depth. Moats are better developed along the east and south sides of the mounds reaching up to $1270-1530$ mbsl at their bases.

The vulnerable deep-sea habitats identified within the PoL (Figure 8) can be resumed into the next types (see details in the Supplementary Table S2):

(1) Deep-Sea hexactinellid sponge aggregations intermixed with Actiniarian communities covering the soft, muddy sea floor of the summit of some mounds (e.g., M1 mound) at $830-850$ mbsl.

(2) Sea-pens communities and aggregations of bamboo corals covering soft muddy bottoms with some coral rubble along the flanks of some mounds (e.g., M1 mound) at 1020-1100 mbsl.

(3) Aggregations of stony octocorals and of soft corals colonizing volcanic rock ridges (Volcanic Ridge) and single volcanic cones (e.g., Volcancito Hill) at 1020-1265 mbsl. 
(4) Deep-Sea Desmosponges aggregations on deep giant circular depressions (Western and Eastern Twin Pools) covered by thin layers of fine sediments at 1200-1300 mbsl.

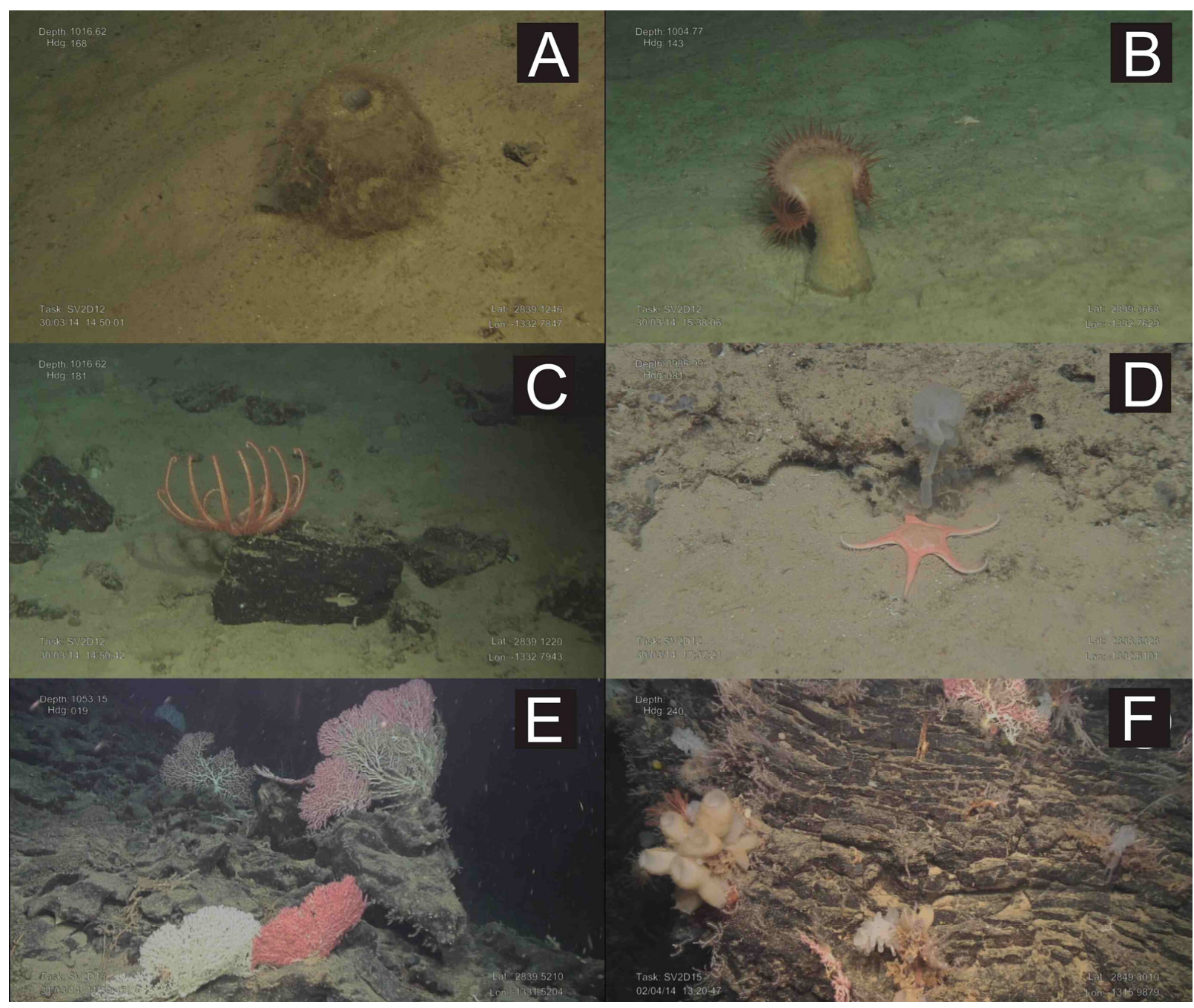

Figure 8. Underwater images obtained with the ROV "Luso"during the SUBVENT- 2 expedition along the PoL. (A): The hexactinellid sponge Pheronema carpenteri on soft substrates of the northern flank of M1 mound; (B): A Venus fly-trap anemone on soft substrates of the northern flank of M1 mound; (C): Brissingid starfishes colonizing small volcanic rocks at the summit of M1 mound; (D): The starfish Nymphaster arenatus on volcanic rocks at the summit of M1 mound; (E): Large colonies of the stony octocorals Corallium spp. (C. niobe and C. tricolor) on basaltic rocks of the volcanic ridge located at the northeastern part of M1 mound; (F): Basaltic rock colonized by different glass sponges, octocorals (Corallium, Swiftia) and hydrozoans at the Volcancito Hill. See Figure 7 for location.

Mounds along the PoL harbor a mixture of fauna from typical sedimentary and rocky habitats, including the hexactinellid sponge (Pheronema carpenteri), venus flytrap anemones, isolated stony octocorals (Corallium) and bamboo corals (Acanella arbuscula), decapod crustaceans (A. foliacea, P. edwardsianus), starfishes (Hymenodiscus, Nymphaster), holothurians (Mesothuria), and leather sea urchins (Araeosoma).

The volcanic ridges and volcanic cones are colonized by a wide variety of suspensionfeeding species, such as stony octocorals (mainly C. tricolor and C. niobe), black corals (Leiopathes glaberrima), bamboo corals (A. arbuscula), and small and large gorgonians (Swiftia, Plexaurid gorgonians), together with crinoids and hexactinellid and lithistid sponges, among a wide variety of benthic species. Some areas covered by abundant coral rubble were colonized by isolated bamboo corals (A. arbuscula). The occurrence of strong bottom 
currents supports the fact that tree-like branches of some octocorals are oriented along an $\mathrm{E}-\mathrm{W}$ direction (Figure 8E)

Giant circular depressions, such as WTP and ETP (Figure 7), contain a mixed seabed with soft and carbonated flagstones. The sandy and muddy substrates are colonized by typical sedimentary bathyal species such as sponges (Thenea), cerianthids, sea-pens (Pennatula), echinoderms (Ceramaster, Mesothuria, Araeosoma), decapods (A. foliacea, P. edwardsianus, Plesionika spp.) and large scalpellid barnacles. The rocky substrates are covered by a layer of sediment that is poorly colonized by fauna, including some massive demosponges (Pachastrellid-like sponges), small encrusting sponges, scattered hydroids and solitary scleractinians (Caryophyllia).

4.1.4. Case Study 4: Low-Temperature Hydrothermal Habitats at Tagoro Volcano, El Hierro Island $\left(27^{\circ} 35^{\prime} \mathrm{N}\right)$

Recent submarine eruptions in El Hierro Island from 2011 to 2012 have provided the opportunity to map the development of a new submarine volcano, named as Tagoro, and the identification of habitats and communities associated with emissions of large quantities of iron and carbon dioxide from hydrothermal submarine vents.

The El Hierro eruption started on 10 October 2011, within a pre-existing submarine valley at 250-350 mbsl (Figure 9A). Initial bathymetric data collected on 25 October 2011, [49] identified a single cone around 205 mbsl (Figure 9B). MBES data from 29 November 2011 , indicated that this volcano developed four vents with summits at 220,195, 180 and 165 mbsl [34]. On 22 December, new bathymetric data showed a drastic collapse of the main edifice that was not present in previously acquired bathymetry. On 6 March 2012, the extrusive magmatic activity ceased 137 days after the onset of the eruption, leaving the summit of the new submarine volcano at $89 \mathrm{mbsl}$. Hydrothermal activity with intensive bubbling released from active vents continued until at least June 2012.

ROV observations in 2014 showed that the base of the Tagoro volcano is dominated by an area with extensive accumulations of scoriaceous bombs at 280 to $380 \mathrm{mbsl}$ formed from basanitic lava emissions (Figure 9C,E,F). When observed closely, these bombs appeared to be either whole intact lava balloons or broken fragments of larger balloons. These bombs correspond to lava balloons floating on the sea surface during the eruption (Figure 9E). Echosounder images of the water column taken during the eruption overlie on the 3D multibeam bathymetry model showed high-reflective bright spots interpreted as these floating bombs sank along the flanks of the volcano (Figure 9A).

Two main habitats were recognized after two years of the cessation of the eruption (see details in Supplementary Table S2):

(1) Chemosynthesis-based habitats composed by a great proliferation of orange-brown Fe-oxidising bacteria draped the whole seafloor of the summit.

(2) Volcanic caves communities along the flanks of the volcano composed by small oysters and serpulids, shrimps and eels.

ROV images of the summit of the volcano show $5 \mathrm{~m}$-high chimneys or hornitos with numerous degassing conduits punctuating their walls and marked by yellow mats, linked to sulfur-related bacteria (Figure 9D). Temperatures measured during the 2014 survey (Supplementary Table S1) showed abrupt increases in temperature up to $\sim 2.69^{\circ} \mathrm{C}$, related to active hydrothermal chimneys or hornitos located at the volcano summit [50]. Peaks of $\mathrm{CO}_{2}$ emissions were detected with the ROV sensors around these hornitos [50]. On the contrary, the flanks of the volcano showed recolonization of fauna such as small oysters (Neopycnodonte cochlear) and serpulids, shrimps (mainly Plesionika), and eels (Conger conger, Gymnothorax) living on caves and crevices generated by the cooling of the plastic bulbous lavas flowing downslope at 250-300 mbsl. 


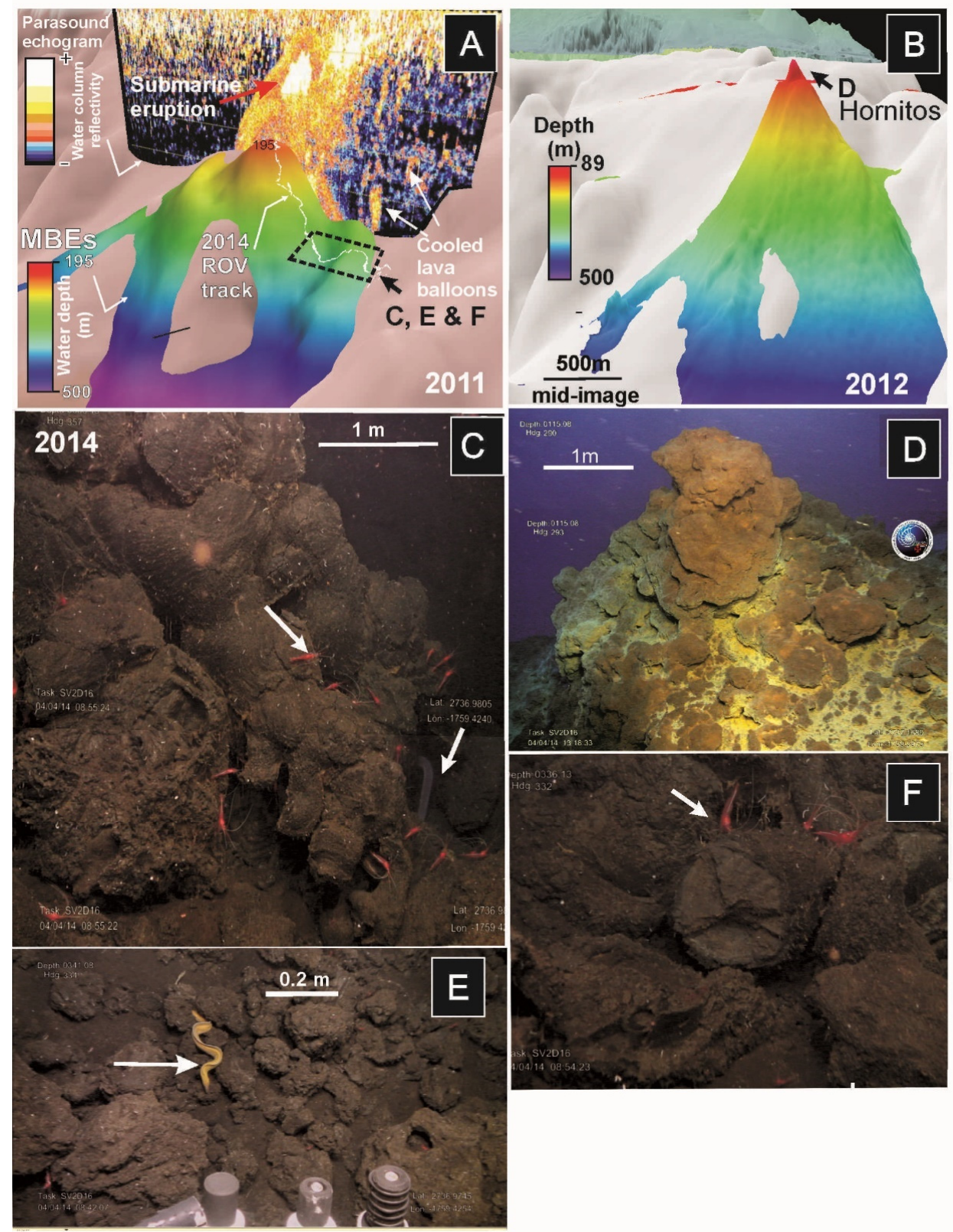

Figure 9. Sequence of MBES during and after El Hierro submarine eruption superimposed on previous bathymetry (in white colour): (A) Bathymetry from November 2011 during the eruption when the summit was located at $220 \mathrm{mbsl}$. Overlay on the bathymetry, a 2D image of parasound echosounder showing the volcanic eruption rising throughout the water column; (B) Bathymetry after the eruption in June 2012 (summit located at $89 \mathrm{mbsl}$ ). ROV images taken in April 2014 showing distinct habitats developed after the eruption: (C) Pillow-lavas flowing downslope with abundant shrimps (mainly Plesionika), serpulid worms and small oysters (Neopycnodonte cochlear, some of the small white dots on the rocks); (D) Hornitos (hydrothermal vents) developed the summit of the volcano draped by yellow and orange iron-sulfide bacterial mats; (E) Lava balloons along the slope of the recent volcano showing demersal fauna such as moray eels (Gymnothorax); and (F) Accumulations of lava bombs colonized by shrimps (Plesionika).

4.1.5. Case Study 5: Ferromanganese Crust-Bearing Seamounts of Southern Canary Islands $\left(23^{\circ} 48^{\prime} \mathrm{N}-26^{\circ} 30^{\prime} \mathrm{N}\right)$

In this fifth case study, we present the data from four ferromanganese crust-bearing seamounts (Echo, The Paps, Drago, and Tropic) located in the west-southwest region of the CISP at water depths ranging from 300 to 4300 (Figure 10). The Echo Seamount is a 
sub-circular seamount of $10 \mathrm{~km}$ in diameter with the flat shallow summit located at only $300 \mathrm{mbsl}$ and the base at $-3700 \mathrm{mbsl}$ (Figure 10A). The Paps seamount has the shape of a NW-SE ridge, $40 \mathrm{~km}$ length in the SE direction with the summit at $1600 \mathrm{mbsl}$ and the base at $4300 \mathrm{mbsl}$ (Figure 10B). The Tropic seamount is a star-shaped guyot, with its base located at $4200 \mathrm{mbsl}$ and its summit at about $1000 \mathrm{mbsl}$ (Figure 10C). The Drago Seamount is elliptical in shape with major axis NW-SE oriented. The summit is situated at 2200, whereas the base at $3000 \mathrm{mbsl}$ (Figure 10D).

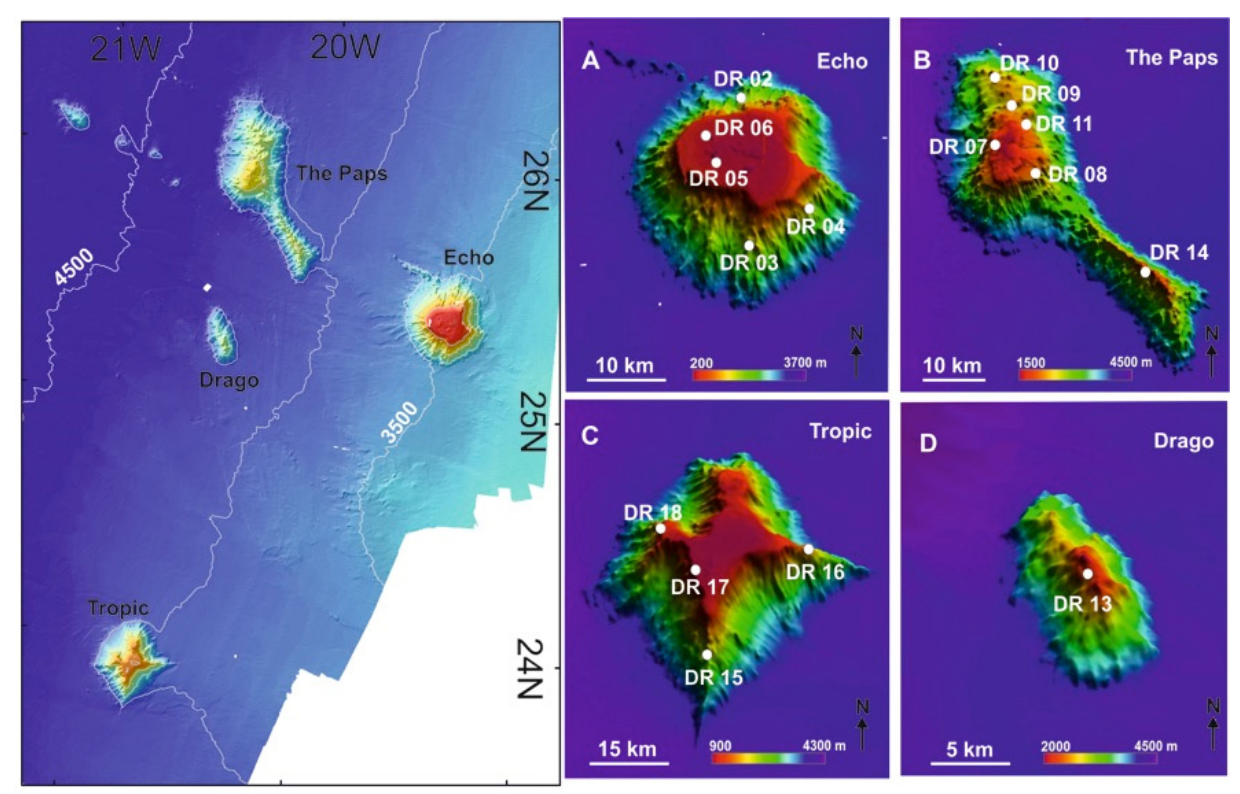

Figure 10. Location of the studied seamounts in the southwestern part of the Canary Islands Seamount Province (CISP) including the positions of the benthic dredge samples (DR) in (A): Echo Seamount; (B): The Paps Seamount; (C): Tropic Seamount; (D): Drago Seamount. See Supplementary Table S2.

The full list with the ROV data including substrate, morphology, water depth, oceanographic values, and associated taxa for each of the seamount surveyed can be found in the Supplementary Table S2. The habitats identified within the surveyed seamounts (Figure 11) can be resumed into the next types (Supplementary Table S3):

(1) Aggregations of scleractinians, sponges and antipatharians on the summits of shallow seamounts ranging from 300 to $1000 \mathrm{mbsl}$ covered by ferromanganese crusts.

(2) Aggregations of gorgonians, antipatharians and bamboo corals along the flanks of shallow seamounts ( $>1000 \mathrm{mbsl})$.

(3) Aggregations of gorgonians, stony corals and deep-sea hexactinellid sponges on the summits and flanks of the deep seamounts (1600-2200 mbsl) covered by ferromanganese crusts.

The summits of shallow guyot-like seamounts (e.g., Echo Seamount) are colonized by habitat-forming species from hard substrates such as large sponges (Pachastrella, Poecillastra), scleractinians (mainly Dendrophyllia cornigera) and antipatharians (Stichopathes) (Figure 11A,B). Other dominant fauna includes molluscs (Asperarca nodulosa, Clelandella, different muricids), small hydroids and echinoderms (mainly cidarids and the crinoid Thalassometra cf. lusitanica). The southern flank of this shallow seamount (DR03, 1757-1949 mbsl, in Figure 10A) showed a higher abundance of sessile species that included large gorgonians (Metallogorgia melanotrichos), small encrusting sponges as well as antipatharians (Bathypathes) and different serpulids (Figure 11C,D). Solitary and colonial scleractinians (Desmophyllum-like corals, Solenosmilia variabilis), bamboo corals, and large brachiopods were also collected in that area (Figure 11E). 


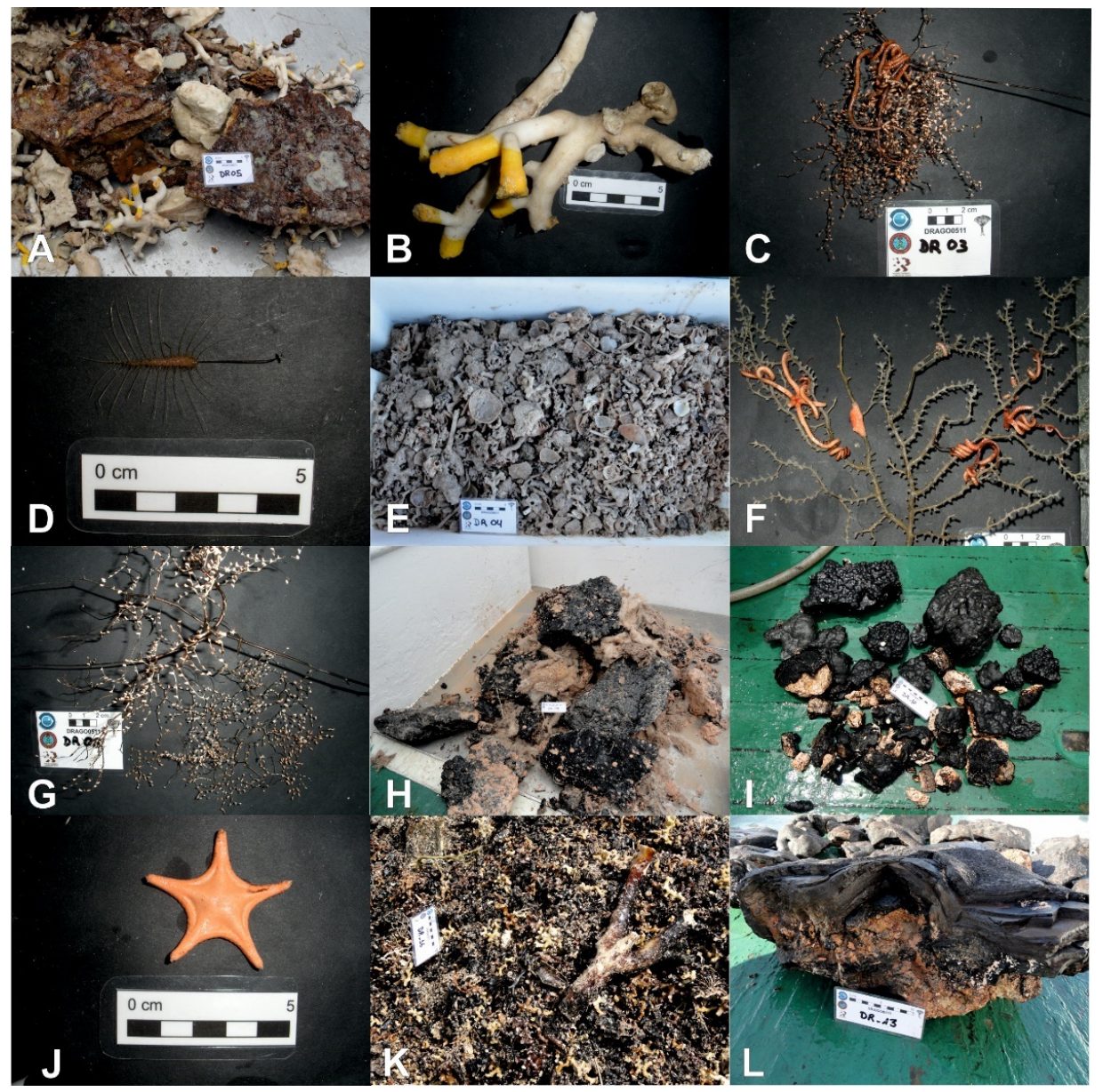

Figure 11. Images of some samples obtained during the DRAGO0511 expedition [48] in the Echo (A-E), The Paps (F-J), Tropic (K) and Drago (L) seamounts at the Canary Islands Seamount Province. (A): Rocks, sponges and corals; (B): A living colony of the scleractinian Dendrophyllia cornigera collected at the summit; (C): A gorgonian (Metallogorgia melanotrichos) harboring an euryalid ophiuroid collected at the flank; (D): A small antipatharian (Bathypathes) collected at the flank; (E): Coral rubble retrieved from the SE flank; (F): Holaxonian gorgonian with abundant epibionts captured at the summit; (G): Metallogorgia gorgonian collected at the summit; (H): Fe-Mn crusts and hexactinellid sponges retrieved from the summit; (I): Fe-Mn crust samples obtained at the flank; (J): Goniasterid starfish collected at the flank; (K): Coral rubble of scleractinians (mainly Solenosmilia variabilis and Desmophyllum-like cup corals) collected at the eastern; (L): Thick Fe-Mn crust on volcanoclastic rock substrate retrieved from the summit.

Ferromanganese crusts of The Paps Seamount (Figure 10B) are colonized by large and fragile deep-sea gorgonians (Metallogorgia melanotrichos, Chrysogorgia, Paramuricea) (Figure 11F-H), bamboo corals, and small soft corals (Anthomasthus), hexactinellid sponges (Aphrocallistes), together with crustaceans (Munidopsis) and echinoderms that are generally attached to the gorgonians (mainly the ophiuroids Ophiocreas and Asteroschema, as well as Antedonidae crinoids). The ferromanganese crust substrate of the northern flank of this seamount (DR10, 2839-3010 mbsl in Figure 10B) is colonized by hexactinellid sponges, gorgonians (M. melanotrichos) and echinoderms (brisingid and goniasterid starfishes, Figure 11I,J, ophiuroids on the gorgonians, e.g., Ophiocreas and Asteroschema).

The ferromanganese crusts and carbonate-phosphorite pavements of the guyot-like Tropic Seamount (Figure 10C) are colonized by scleractinians (mainly Solenosmilia variabilis and Desmophyllum-like solitary corals) (Figure 11K), large colonies of bamboo corals (Acanella, Keratoisis up to $60 \mathrm{~cm}$ long), hexactinellid sponges (mainly Poliopogon amadou), polychaetes (mainly eunicids), and stalked crinoids (Endoxocrinus wyvillethomsoni). The 
associated fauna included hexactinellid sponges, antipatharians (Bathypathes), ophiuroids, polychaetes and crustaceans (Munidopsis, balanids, pandalid shrimps).

The deepest seamount, the Drago Seamount (Figure 10D), harbored colonies of stony octocorals (Corallium) and the gorgonian M. melanotrichos, together with hexactinellid sponges (Aphrocallistes, Regadrella) and small unidentified gorgonians at its summit (DR13, 2290-2426 mbsl, Figure 10D) colonizing thick ferromanganese crusts (Figure 11L).

\section{Discussion}

\subsection{Potential Drivers of Deep-Sea Habitat Distribution from Subtropical North Atlantic}

This section discusses the potential drivers affecting the distribution and biodiversity of vulnerable deep-sea habitats, including both chemosynthesis and non-chemosynthesisbased habitats. Some of these drivers are: (a) the seafloor water mass properties as temperature, salinity, dissolved oxygen and potential density [12]; and (b) the active geological processes affecting the seafloor such as (i) methane seeps [51-55] and (ii) submarine volcanic eruptions followed by low-T hydrothermal degasification [50]. Furthermore, an overview of the effects of methane seeps and low-T hydrothermal vents following recent submarine eruptions on the distribution of deep-sea habitats at regional scale along the northeast Atlantic Ocean from $24^{\circ} \mathrm{N}$ to $42^{\circ} \mathrm{N}$ is provided.

\subsection{Influence of Water Mass Properties on Vulnerable Deep-Sea Habitats}

The relationships between water depths and water mass properties (temperature, salinity, dissolved oxygen, and potential density) for specific vulnerable deep-sea habitats highlight important considerations on suitable environmental conditions for them. The distribution of undercurrents along the NE Atlantic from the NW African Margin and Canary Islands to the north Iberian Margin is mainly driven by the outflow of the MOW at the Gibraltar Strait and by the intrusions of the Antarctic-derived AAIW currents at intermediate waters (Figure 12). The ROV-mounted CTDs data are in-situ measurements of the benthic layer, where the deep-sea habitats allow us to compare the regional distribution of water masses (Figure 12) with the local variables affecting the specific habitats (Figures 13-15). A full list of oceanographic measures in-situ for each site surveyed with the ROV-mounted CTD is shown in Supplementary Table S3.

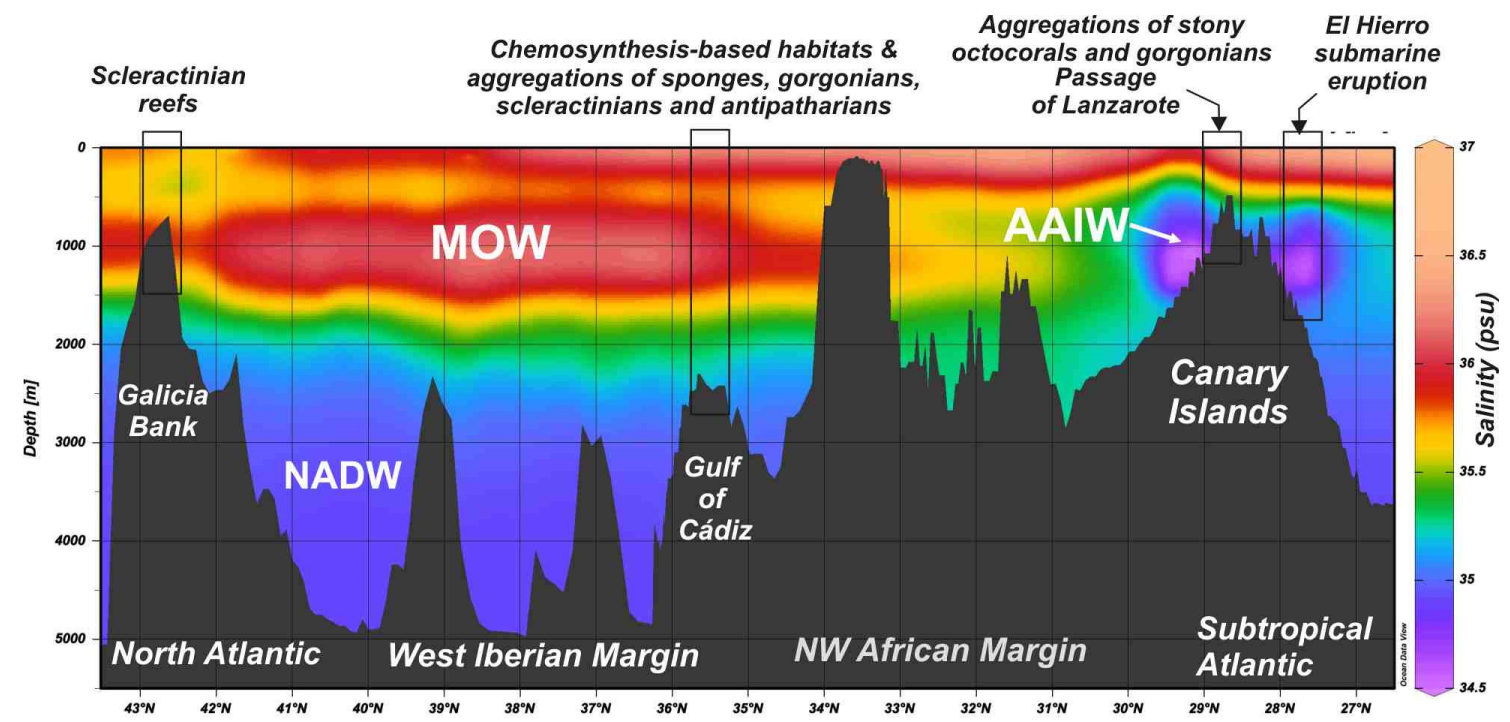

Figure 12. Distribution of water masses from the Subtropical Atlantic to the North East Atlantic based on regional salinity values. Mediterranean Outflow Waters are mainly flowing northwards from the Gibraltar Strait affecting the Gulf of Cádiz and west Iberian Margin. Otherwise, Antarctic Intermediate Waters are flowing northwards along the NW African Margin throughout the Passage of Lanzarote. Data from World Ocean Database 2018 [44]. 

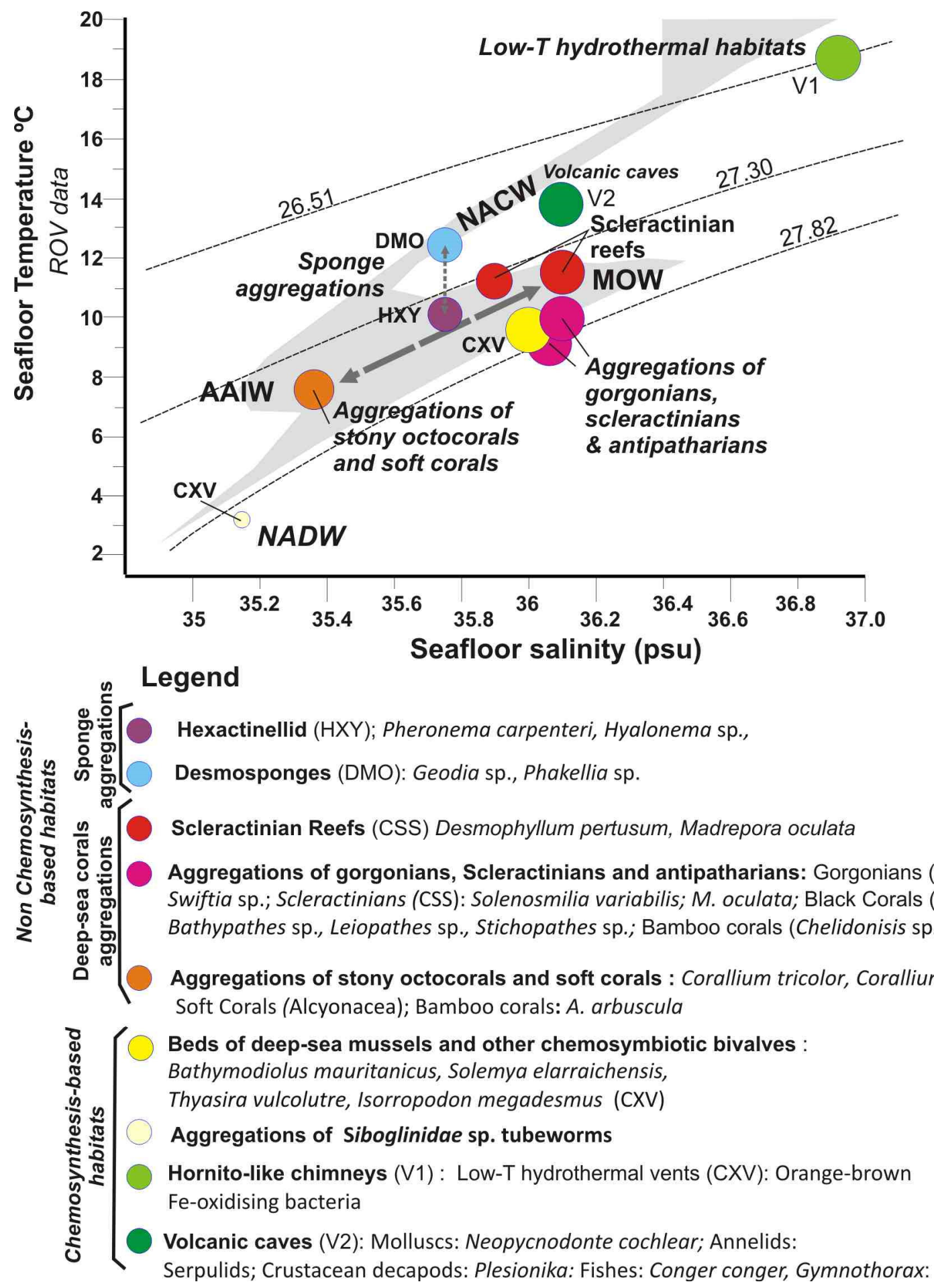

Figure 13. T-S diagram for the in-situ water mass conditions measured with the ROV for each of the type of habitats (full data listed in Supplementary Table S3). Background grey pattern corresponds to CTD data and dashed lines (from top to bottom) to constant potential density (isopycnal) contours $=26.51,27.30$ and 27.82 dividing four regions corresponding to the main different water masses defined by [33]: NACW, AAIW, MOW and NADW defined by [33]. Legend: FAO Taxa Classification and Codes for Vulnerable Marine Ecosystems (VMEs) (http:/ / www.fao.org/in-action/vulnerable-marineecosystems/vme-database, accessed 1 December 2020). 

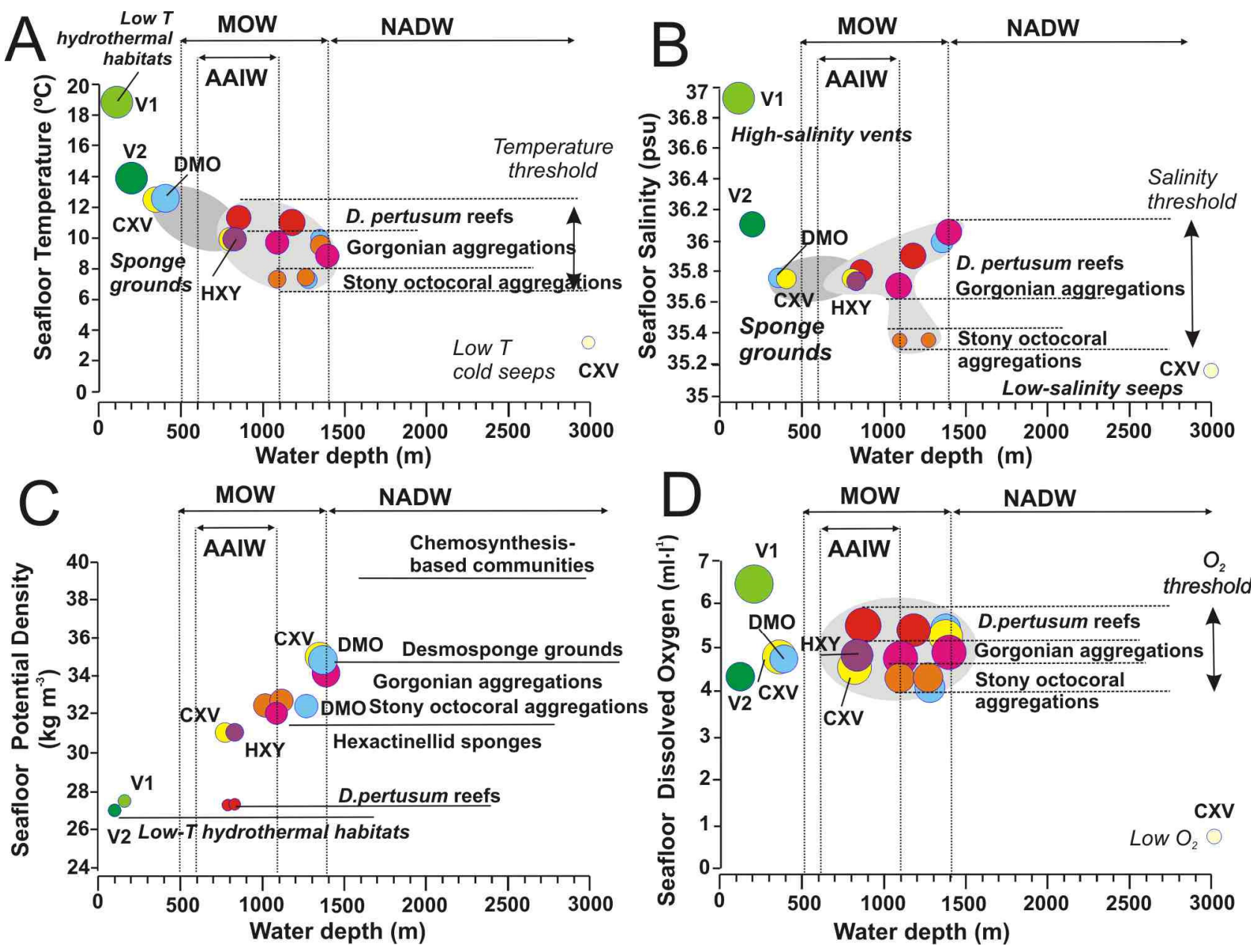

Figure 14. Seafloor water mass parameters vs. water depths for each of the identified vulnerable deep-sea habitats and their exposure to the main bottom currents: (A) Temperature; (B) Salinity; (C) Potential Density, and (D) Dissolved Oxygen. Color legend for deep-sea habitat types is the same as Figure 13. AAIW: Antarctic Intermediate Water current; MOW: Mediterranean Outflow Water; NADW: North Atlantic Deep-Water current. Data are full listed in Supplementary Table S3. Further explanation in the text.

Figure 13 shows the T-S diagram for the in-situ water mass conditions measured for each type of habitat (data can be found in Supplementary Table S3). In this T-S diagram, most of vulnerable deep-sea habitats are located within the field of the intermediate waters: AAIW and MOW bounded between 27.30 and 27.82 isopycnals.

The three types of deep-sea coral habitats are located between these two intermediate water masses. Therefore, the aggregations of stony octocorals and bamboo corals along the PoL are bathed by AAIW, which is reflected by a clear $S$ minimum $(S=35.4)$. Otherwise, aggregations of gorgonians, scleractinians, and antipatharians of the $\mathrm{GoC}$ as well as scleractinian reefs of the GB are bathed by the MOW, characterized by warmer and saltier waters $(\mathrm{S}=35.8-36.2 \mathrm{psu})$. On the contrary, the sponge aggregations seem to follow a distinct pattern, with those of Desmosponges related to the NACW at uppermost levels in the PoL, whereas those of Hexactellinids in the GoC related to intermediate waters MOW-AAIW. The main difference in the water masses of these two types of sponge aggregations is the $\mathrm{T}$ values (Figure 13). 

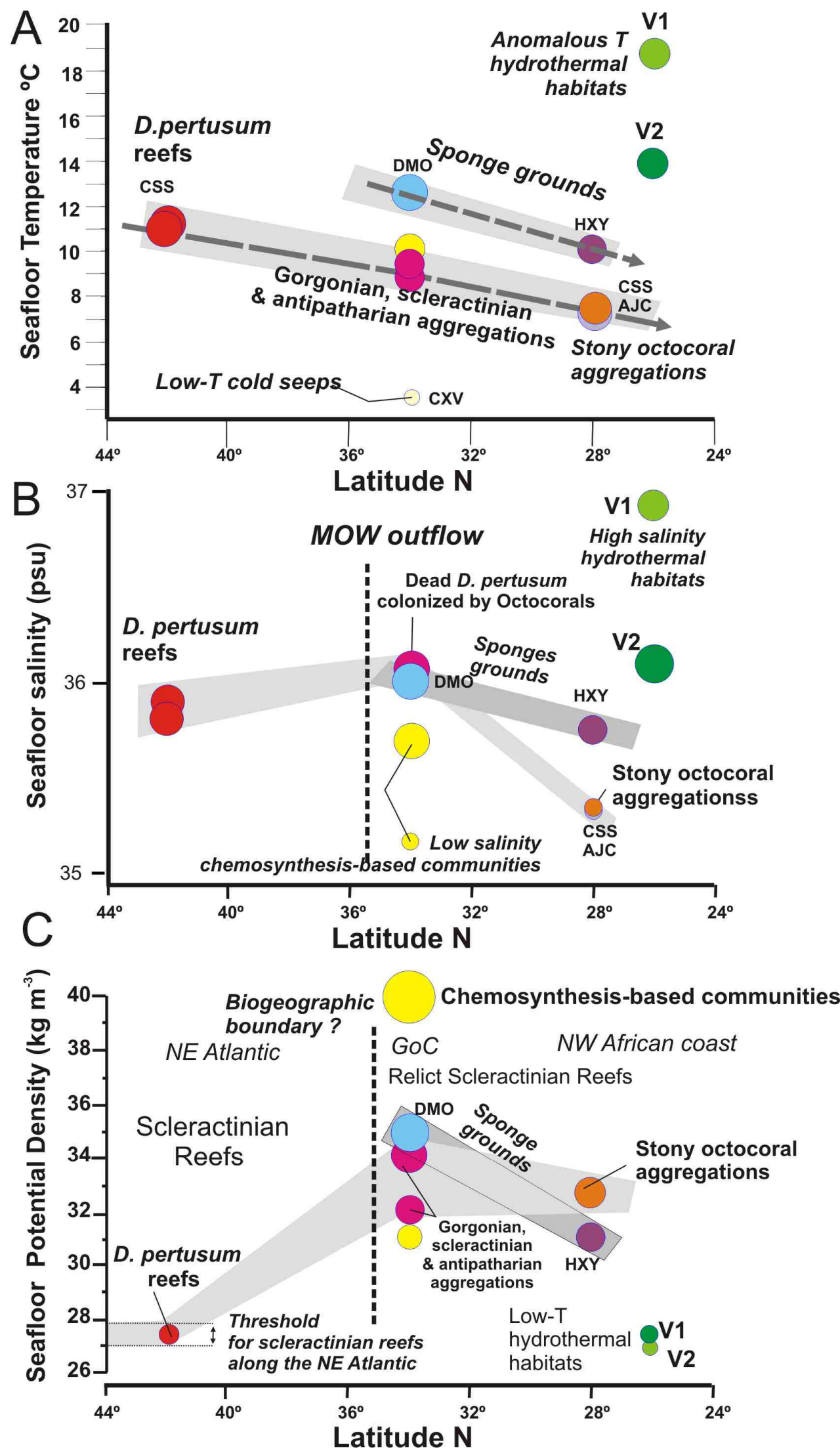

Figure 15. Seafloor water mass parameters vs. latitudes for each vulnerable deep-sea habitat detected in this study: (A) Temperature; (B) Salinity; and (C) Potential Density. Colour legend is the same as in Figure 13. 
Chemosynthesis-based habitats of the GoC are also located under the influence of the MOW, except for the deepest mud volcano (e.g., Bomjardim MV), which is located under the influence of the NADW. The values for low-T hydrothermal habitats of the summit of the Tagoro volcano with high $S$ and $T$ are disturbed by the influence of hydrothermal fluids not reflecting its location at the thermocline. In contrast, benthic habitats of volcanic caves at the flanks of Tagoro are bathed by the NACW reflecting the major influence of water masses (Figure 13).

\subsubsection{Water Mass Temperatures}

Water temperature has been traditionally considered as one of the most important factors influencing the distribution of deep-sea organisms due to their different physiological tolerances $[12,56]$. Thermal thresholds for deep-sea coral habitats (including those conformed by scleractinians, stony octocorals, gorgonians, and black corals) are well constrained to temperature ranges of 7.3 and $11.5^{\circ} \mathrm{C}$ within the depth range of $800-1400 \mathrm{~m}$ (Figure 13A). Within this threshold, all these deep-sea corals appear distributed into three levels of seafloor temperatures: (i) scleractinians conforming reefs (Desmophyllum pertusum, and Madrepora oculata) located at the maximum temperature tolerance of $11-11.5^{\circ} \mathrm{C}$; (ii) Gorgonians, scleractinian and antipatharians conforming aggregations at intermediate temperatures of $8.8-10^{\circ} \mathrm{C}$; and finally iii) Stony octocoral aggregations at the lowest temperatures of $7.3-7.7^{\circ} \mathrm{C}$ (Figure $\left.14 \mathrm{~A}\right)$.

The temperature range of the distribution of the reef-forming scleractinians $D$. pertusum and $M$. oculata $\left(4-12^{\circ} \mathrm{C}\right)$ across the five case studies matches the temperature range of cold North Atlantic Intermediate waters and the temperature range where those reefforming species have been detected in the past [56,57].

On the other hand, some aggregations of fragile octocorals (Acanella, Radicipes) appear at the lowest temperatures of 7.3-7.7 ${ }^{\circ} \mathrm{C}$ (Figure 14A) in the case studies but at a higher temperature range $\left(1.5-6.1^{\circ} \mathrm{C}\right)$ than that detected previously for the North Atlantic, so the present study provides new data for case studies located southwards of those considered [58]. Moreover, the low temperature values could point out that stony octocoral gardens living along the PoL are somehow influenced by the cold Antarctic Intermediate Waters (AAIW) that flows between the easternmost Canary Islands and the African margin (Figures 12 and 13), which was totally unexpected previously in this study.

Otherwise, desmosponges aggregations dominated by Geodia sp. and Phakellia sp., occurring within the crater of Mercator MV (Figure 5D) at shallow depths of 350-370 mbsl, tolerate high sea-floor temperatures up to $12.5^{\circ} \mathrm{C}$ (Figure $14 \mathrm{~A}$ ) as also detected in the northern sector of the GoC, where the MOW influence is higher [54]. On the contrary, hexactinellid sponge aggregations with Pheronema and Hyalonema detected along the flanks of the Algacel MV at 820-840 mbsl (Figure 5E) live within the thresholds of the aggregations of gorgonians, scleractinians, and antipatharians, colonizing MDACs around methane seeps (Figure 14A). Indeed, these sponges were found at similar depths and environmental conditions in the northern part of the GoC $[59,60]$. On the other hand, deep-sea chemosynthesis-based habitats do not show seafloor temperature constraints, varying from 3.2 to $12.5^{\circ} \mathrm{C}$, as function of the seeps location. In the case of the large mussels Bathymodiolus mauritanicus, the seafloor temperature of $10.1^{\circ} \mathrm{C}$ may fluctuate as function of intensification of the hydrocarbon seeps. No information on the effect of temperature on the distribution of methane seeps fauna has been found, but the fact that the same chemosymbiotic-species may occur in cold seeps with different oceanographic conditions in methane seeps of the northern and southern GoC may indicate a lower dependence on water mass properties for these chemosymbiotic organisms than for the above mentioned cnidarians and sponges $[60,61]$. In the case of the hydrothermal-related habitats (V1 = hornitos-like hydrothermal chimneys and V2 = lava cavities in Figure 14A), temperatures reflect thermal anomalies associated with venting hydrothermal fluids. Therefore, maximum measured temperature of expelled fluids in Tagoro volcano was $39^{\circ} \mathrm{C}$, while the 
ambient seawater range between 15 and $19^{\circ} \mathrm{C}$ with local temperature anomalies of $+2.7^{\circ} \mathrm{C}$ associated with $\mathrm{CO}_{2}$ emissions [50].

\subsubsection{Salinity and Potential Density}

Although salinity variations are very low in the deep sea, the distribution of deep-sea scleractinians and octocorals in some areas of the NE Atlantic has been related to potential density, which represents a parameter defined by salinity and temperature [62]. Indeed, reef-forming scleractinians of the selected sites are controlled by a narrow salinity range of 35.35-36.1 psu (Figure 14B). As seafloor temperatures, habitats conformed by deep-sea corals appear also distributed into three levels of salinity: (i) Scleractinian reefs (D. pertusum and M. oculata) occurred at salinity ranges between 35.8 and 36.1 psu; (ii) Gorgonian aggregations at salinity ranges between 35.6 and $36.1 \mathrm{psu}$; and (iii) Stony octocoral aggregations at the lowest salinity values between 35 and $35.2 \mathrm{psu}$. These data point out that there is an influence of the MOW waters bathing the scleractinian reefs, and of the mixing between the saltier MOW waters and the lower salinity AAIW waters for some gorgonian and stony octocoral aggregations (Figure 13). Indeed, the MOW flow seems to play an important role in the distribution and connectivity of deep-sea corals across the NE Atlantic, with a high diversity of deep-sea corals along the MOW pathway [63].

Deep-sea desmosponges aggregations at $1400 \mathrm{mbsl}$ appear associated with salty water masses of 36 psu (Figure 13B) related to the export of bathyal benthos to the Atlantic through the MOW outflow as detected in other areas of the GoC [60]. On the contrary, shallow water desmosponges grounds associated with methane seeps of the Mercator MV (Figure 5C), located at $350 \mathrm{mbsl}$ above the MOW influence, show the lowest levels of salinity of $35.75 \mathrm{psu}$ (Figure 14B). As occurred for temperature values, large hexactinellid sponge aggregations occurred within the same salinity range as for deep-sea corals (Figure 14B). The role of the MOW exporting deep-sea sponge larvae from the Mediterranean to the Atlantic Ocean and some NE locations close to the GoC has been demonstrated recently, and this may partly explain the occurrence of some sponges in salty water masses related to the MOW [64].

The occurrence of scleractinian reefs along the NE Atlantic margins has been related to values of potential density, a parameter defined by salinity and temperature. Thus, D. pertusum and $M$. oculata reefs, were firstly constrained to a narrow potential density range (potential density; $\delta_{\theta}=27.35-27.65 \mathrm{~kg} \mathrm{~m}^{-3}$ ) [62] which further, in other North Atlantic regions, proved to be larger than initially suggested as ranging $\delta_{\theta}=27.10-27.84 \mathrm{~kg} \mathrm{~m}^{-3}$ [63]. This range is similar for the D. pertusum and $M$. oculata reefs identified in the Galicia Bank, which falls within this suggested range with values of $\delta_{\theta}=27.353-27.431 \mathrm{~kg} \mathrm{~m}^{-3}$ (Figure 14C). In the case of the Galicia Bank, these conditions seem to be caused by the turbulent mixing between the MOW and the ENACW water masses promoted by the MOW current impinging the topography of the Galicia Bank [46]. The formation of turbulent eddies of MOW flow facilitates the downward transport of nutrients, influencing the present distribution of the scleractinian reefs and mounds mapped along its flanks and on the summit (Figure 3B).

On the contrary, the gorgonian and stony octocorals aggregations do not fit with this potential density threshold (Figure 14C). Thus, stony octocoral aggregations in the subtropical latitudes occur at potential density values $\delta_{\theta}=32.725 \mathrm{~kg} \mathrm{~m}^{-3}$, whereas gorgoniandominated aggregations occur at values of $\delta_{\theta}=32.050-34.900 \mathrm{~kg} \mathrm{~m}^{-3}$, much higher than those for scleractinian reefs. Thus, according our data, the potential density range proposed for scleractinian reefs $[62,63,65]$ would be only valid for the northernmost NE Atlantic margins, and more data on the presence of these species southwards is then needed for estimating the appropriate density range. One explanation is the potential influence of intrusion of AAIW flow along the NW Africa margin towards the GoC (Figure 12).

Desmosponges and hexactillenid aggregations also show different potential densities. Therefore, desmosponge aggregations show higher potential density ranges $\left(\delta_{\theta}=32.050-34.900 \mathrm{~kg} \mathrm{~m}^{-3}\right)$ than the studied hexactillenid sponge aggregations 
$\left(\delta_{\theta}=31.058 \mathrm{~kg} \mathrm{~m}^{-3}\right)$ (Figure 14C) Hydrography plays an important role in shaping the distribution of sponge aggregations in the Atlantic, and several authors have noted the association of sponges with particular water masses due to their temperature and salinity characteristics or hydrodynamic conditions, such as tides or internal waves which enhance the food supply. Thus, the influence of the NACW (Figure 13) in the study area allows the presence of desmosponges assemblages with a wide Atlanto-Mediterranean distribution $[60,64]$.

\subsubsection{Dissolved Oxygen Concentrations}

Dissolved oxygen (DO) values are close to saturation in most deep-sea areas, ranging from $2.5 \mathrm{~mL} \cdot \mathrm{L}^{-1}$ off SW Africa to $6 \mathrm{~mL} \cdot \mathrm{L}^{-1}$ in the NW Atlantic [65]. The values of DO for deep-sea corals in the study area are limited to values ranging from 4.3 to $5.5 \mathrm{~mL} \cdot \mathrm{L}^{-1}$ (Figure 14D). As occurred with temperature and salinities values, these habitats show three levels of DO for deep-sea coral habitats living at 800-1400 mbsl: (i) High oxygenation values of $5.44-5.55 \mathrm{~mL} \cdot \mathrm{L}^{-1}$ for scleractinian reefs; (ii) Intermediate oxygen values of $4.73-5.25 \mathrm{~mL} \cdot \mathrm{L}^{-1}$ for gorgonian aggregations; and (iii) low oxygen values of $4.32 \mathrm{~mL} \cdot \mathrm{L}^{-1}$ for stony octocorals aggregations. Otherwise, desmoponges sponge grounds show similar values of DO to aggregations of gorgonians and stony octocorals (Figure 14D). Deep-sea corals and sponges, like other organisms, are not very sensitive to small variations in DO unless it drops a certain threshold [12].

Otherwise, hypoxic or anoxia conditions are mainly related to submarine areas with methane seeps or hydrothermal vents. Seafloor anoxic conditions may be generated by intense activity of methane seeps, hydrothermal vents or submarine eruption plumes. Fluid emissions are not continuos but may be reactivated periodically on focused submarine vents or remain diffuse during long time [66]. Very low DO values of $0.64 \mathrm{~mL} \cdot \mathrm{L}^{-1}$ observed on deep-water mud volcanoes as Bonjardim in the GoC are closely to anoxia suggesting the intense activity of methane seeps (Figure 14D). If methane seeps are intense and/or undercurrents are weak in such deep waters, then low oxygen conditions prevail above seafloor and chemosynthesis-based habitats are only composed by colonies of Siboglinidae tubes [67]. However, in areas of methane seeps influenced by strong intermediate undercurrents (Figure 14D), co-occurrence of chemosynthesis-based and scleractinian-gorgonian aggregations has been detected as in this study and other MVs of the Gulf of Mexico [68]. This is the case for the extensive beds of deep-sea mussels Bathymodiulus mauritanicus beds living around bubbling methane seeps (Figure 5D) and MDACs patches colonyzed by gorgonians, antipatharians, and scleractinians in Algacel MV (Figure 5D). In such methane seeps, the siboglinids tubeworms play an important role in the connectivity between methane seeps and deep-sea corals by filtering sulphur reducing bacteria (SRB) allowing the predominance of anaerobic oxidation of methane (AOM) by archaeas building up carbonates patches and allows deep-sea coral larvae to grow isolated from the surrounding highly acidic methane muds [69].

\subsection{Distribution of Vulnerable Deep-Sea Habitats from Subtropical to North Latitudes}

The biodiversity of deep-sea habitats and their biogeographical affinities can vary over space and time due to regional and basin-scale changes in the oceanographic conditions [65]. However, active geological process affecting the ocean's seafloor such as methane seeps, hydrothermal vents or submarine eruptions can modulate the spatial distribution of deepsea habitats as detected in this study. The water properties for deep-sea habitats show trends with latitude which are related to oceanographic conditions, but also anomalous values associated with methane seeps and hydrothermal vents (Figure 15). Therefore, deep-sea coral habitats show a notable decreasing trend in the suitable temperatures from north to south (Figure 15A): (i) $11-11.5^{\circ} \mathrm{C}$ for scleractinian reefs habitats in the Galicia Bank; (ii) $8.8-10^{\circ} \mathrm{C}$ for gorgonian and scleractinian aggregations associated with mud volcanoes of the $\mathrm{GoC}$; and (ii) $7.4-7.7^{\circ} \mathrm{C}$ for stony octocoral gardens of the PoL. Otherwise, the sponge grounds show a similar decreasing trend but at higher temperature ranges. 
Thus, desmosponges habitats of the $\mathrm{GoC}$ are related to temperatures thresholds as high as $12.5^{\circ} \mathrm{C}$, whereas hexactillined sponge grounds of the Pol show lower temperatures of 7.3-7.33 ${ }^{\circ} \mathrm{C}$ (Figure 15A). This negative trend identified in the sensitive temperatures for these habitats may be caused by the cooling of the AAIW intermediate waters and it may affect the composition of these communities as identified on T-S diagram (Figure 13). The AAIW flows along the NW African coast and extends to the $\mathrm{GoC}$, where it interacts with the MOW outflow, perhaps restricting the spreading of the later [70].

The values of salinity from $24^{\circ}$ to $44^{\circ} \mathrm{N}$ show a different trend than the temperature ones (Figure 15B). In this case, the deep-sea habitats supporting maximum salinity values are located on the mud volcanoes of the $\mathrm{GoC}$, that are strongly influenced by the MOW undercurrent (Figures 12 and 13). Therefore, gorgonian and scleractinian aggregations growing on MDACs around methane seeps show maximum salinity values up $36 \mathrm{psu}$. Both to the north and to the south, the salinity threshold for deep-sea corals diminishes. Thus, the scleractinian reefs of the Galicia Bank $\left(42^{\circ} \mathrm{N}\right)$ show slightly lower salinity values of $35.9 \mathrm{psu}$ and stony octocoral aggregations located on the PoL $\left(28.30^{\circ}-29^{\circ} \mathrm{N}\right)$ show the lowest salinity values of $35.35 \mathrm{psu}$ (Figure 15B). Considering this, the low salinity and temperature values bathing the stony octocoral aggregations of the PoL are due to the influence of the AAIW flowing along the NW African (Figures 12 and 13).

The salinity threshold for the sponge aggregations follows the same descending trend from 34 to $28^{\circ} \mathrm{N}$ at regional scale (Figure 15B). Desmosponge grounds living close to methane seeps in the GoC are living under similar high salinity values to gorgonian and scleractinian aggregations (Figure 15B). However, hexactillenid sponge grounds living at shallower depths on the summits of the PoL mounds support higher salinity values than stony octocoral habitats (Figure 15B). This is interpreted as a result of the influence of periodic southwards intrusions of salty MOW waters into the PoL at water depths shallower than the AAIW undercurrents which may influence the development of those habitats.

\subsection{Temporal Variability of AAIW Latitudinal Extension along the Northern Atlantic Ocean Might Have Caused the Massive Mortality of CWC Reefs?}

At present live D. pertusum and M. oculata frameworks are very scarce in the $\mathrm{GoC}$ and generally substituted by other deep-sea corals (e.g., different species of gorgonians, antipatharians, etc.). Besides, a geographical boundary between scleractinian reefs and aggregations of other deep-sea corals is observed (Figure 15B,C). A distribution possibly related to the presence of the AAIW waters (Figure 13). Evidence for such a relation is provided by the occurrence of giant dead mounds up to $30 \mathrm{~m}$ in height conformed by dead scleractinians (D. pertusum and M. oculata), such as in the Pompeia Coral Province in the GoC (Figure 4), pointing to a massive mortality of scleractinian reefs off northwest Moroccan [69,71-73] and along the Mauritanian margins [74].

Based on radiocarbon data of scleractinians along the Western Mediterranean Sea during the last deglaciation times [75], we hypothesize that the beginning of intrusion of AAIW waters into the GoC during the last deglacial times may have been one of the causes of a massive mortality of scleractinians by shifting northwards the biogeographical boundary between some scleractinians and stony octocoral aggregations (Figure 15B). This point out that stony octocorals (Corallium tricolor and C. niobe), antipatharians, and gorgonians are more suitable to AAIW conditions than the scleractinians D. pertusum and M. oculata.

\subsection{The role of Methane Seeps Driving Distribution of Chemosynthesis and Non-Chemosynthesis-Based Habitats}

Seabed features formed by seafloor venting of hydrocarbon-enriched fluids are generically termed cold seeps, which are associated with high geological, geochemical and, biological activity [51,52]. Submarine MVs are one of the main seabed morphological expressions of cold seeps formed by violent eruptions, followed by progressive degassing of hydrocarbon-enriched fluids and sediments onto the seafloor [66]. 
5.5.1. Drivers Controlling Distribution of Habitats in Methane Seeps: Acidic Muds vs. Carbonates

Based on the habitat types identified, $\mathrm{ROV}$-mounted CTD parameters and $\mathrm{CH}_{4}$ water analyses along MVs of the GoC, two main drivers controlling their formation and distribution should be highlighted: (i) the rate of release of deep-seated methane-enriched fluids, and (ii) the formation of hard substrates such as MDACs (chimneys, slabs or pavements) by AOM processes [27].

The upward migration of methane is transformed by AOM into large amounts of sulphide on the surface [76]. This extremely acid seafloor is buffered by large populations of sulphur-oxidizing siboglinid tubeworms and sulphur-oxidizing bacterial mats, allowing formation of hotspots on the surface by consuming the AOM-sourced sulphur [69]. The occurrence of siboglinid tubeworms in the anoxic-oxic zone seems to be essential for the formation and the non-dissolution of carbonates at the seabed and, moreover for the progressive colonization by deep-sea corals and other suspension feeders on these hard carbonated substrates. Thus, some scleractinians, gorgonians, antipatharians, bamboo corals, and demosponges can colonize the upper parts of MDACs blocks, slabs and pavements, up to $1 \mathrm{~m}$ in diameter. In areas with extensive hydrocarbon seeps, massive MDACs are the dominant substrate for coral colonization and reef formation as detected in other MVs of the GoC $[54,59]$.

\subsubsection{CWC Mounds and Methane Seeps}

The formation of giant carbonate mounds up to $30 \mathrm{~m}$ high built up by colonial scleractinians has been identified related to methane seeps in the GoC $[69,71,72,77]$. In the case of the Northern Pompeia Coral Ridge (westwards Algacel MV), we identified values of methane ranging from 41.93 to $43.24 \mathrm{nM}$ and patches of shells of chemosymbiotic bivalves, mainly L. asapheus with some Thyasira vulcolutre, and scattered bacterial mats (sulfur-oxidizing-like Beggiatoa) indicating active methane seeps throughout the carbonate mounds. It has been proposed a direct relationship between carbonate reefs and fluid seepages by fertilizing waters sourced from methane seeps [78]. Recently, a new hypothesis on the formation of carbonate mounds conformed by scleractinians has been proposed in relation to methane seeps [69]. Thus, scleractinian larvae may colonize MDACs hotspots only if siboglinid tubeworms previously reduce the concentration of sulfide in the anoxicoxic zone allowing skeletal calcification of scleractinians in MDACs surrounded by the highly acidic muds of methane seeps. Transition from active methane seeps, carbonate mounds and deep-sea coral colonization stages has also been proposed as evolutionary stages of MVs in the GoC [79].

Deep-sea coral colonizing MDACs hard substrates in areas of methane seeps have been reported throughout all margins of the world: The Gulf of México [80,81], Hikurangi Margin in New Zealand [82], Brazilian margin [83], the Darwin Mounds in the northern Rockall Trough [63], the Norwegian shelf [78], and the Porcupine Basin, west of Ireland [84]. Furthermore, the co-existence of chemosymbiotic vestimentiferan worms and bacterial mats with deep-sea corals in cold seeps has been reported in the Gulf of Mexico [81]. The co-occurrence of MDACs with annelids has also been reported from hydrocarbon seeps along the US northern and mid-Atlantic margin [85]. Both MDACs and chemosymbiotic deep-sea mussels in the U.S. Atlantic margin seeps shows average $\delta^{13} \mathrm{C}$ signature of $-47 \%$, a value consistent with microbially driven anaerobic oxidation of methane-rich fluids occurring at or near the sediment-water interface [85]. In these seep areas, macrofaunal densities dominated by annelid families Dorvilleidae, Capitellidae, and Tubificidae were four times greater than those present in deep-sea mussel beds habitats. These differences between chemosynthesis-based habitats have also been observed in the GoC $[59,61]$. In this way, it has been suggested that the difference between habitats in such extremophile environments is driven by quality and source of organic matter [86]. 


\subsubsection{Type of Habitats and Methane Concentration}

Based on this study, a relationship between the type of habitat and methane concentration in the water column may occur: (i) High concentrations of methane $97.60 \mathrm{nM}$ with bubbling: extensive beds of living chemosymbiotic bivalves B. mauritanicus, Lucinoma asapheus, Acharax gadirae, or Thyasira vulcolutre fueled by bubbling gas through fissures and cracks; (ii) Intermediate methane concentrations ranging between 65 and $92 \mathrm{nM}$ : AOM-formed MDACs accumulations colonized by aggregations of gorgonian and antipatharians (Bathypathes, Leiopathes, Stichopathes), bamboo corals (Chelidonisis, Acanella), stony octocorals (Corallium) and, sometimes even scleractinians (D. pertusum) as well as of demosponges; (iii) Low concentration ranging 20-30 nM allowing colonisation of typical non-chemosymbiotic bathyal soft bottom species such as sea-pens (Kophobelemnon sp., Pennatula, Anthoptilum), cerianthids, holothurians and decapods.

The influence of strong undercurrents bathing the flanks of the MVs favours the occurrence of non-chemosymbiotic fauna such as large sponge grounds (Geodia sp., Phakellia sp.) that colonize the scattered MDAC slabs, as well as sea-pens (Funiculina quadrangularis), cerianthids and annelids (Hyalinoeciatubicola) on the soft, muddy sediments.

\subsection{Potential Ecological Restoration of Deep-Sea Habitats after Submarine Eruptions in the Macaronesia Region}

Volcanism and associated hydrothermal systems are relevant processes for the evolution of the ocean basins, due to their impact on the geochemistry of the oceans and their potential to form significant deposits [87]. Low-T hydrothermal vents after violent submarine volcanic eruptions generate long-term $\mathrm{CO}_{2}$ inputs to oceans due to the continuous degasification of the magmatic systems mainly placed on hot-spot volcanic islands like Hawaii or Canary Islands. This is due to the high contents in $\mathrm{C}$ bearing in the thick oceanic sediments below the submarine volcanoes that are expulsed by low-T hydrothermal vent systems [88].

In the Tagoro volcano, recolonization of pioneering fauna such as small oysters, serpulids and mobile species (e.g., shrimps, eels) was detected, representing first colonizers of the newly formed substrates in this volcanic environment. Newly formed habitats were also detected [89] together with the burial of extensive areas with aggregations of antipatharians and some deep-sea corals. Some authors indicated that the first colonizers at Tagoro volcano included a large proportion of common suspension feeders and predators of circalittoral and bathyal hard bottoms of the Macaronesian fauna, which could have exploited the uncolonized hard bottoms and the post eruptive fertilization of water masses $[35,36]$. Along the flanks of this volcano, caves show high values up $6.44 \mathrm{~mL} \cdot \mathrm{L}^{-1}$ of DO related to active $\mathrm{CO}_{2}$ degasification two years after the volcanic eruption [50]. The trend representing the DO range for deep-sea complex habitats from $40^{\circ} \mathrm{N}$ to $26^{\circ} \mathrm{N}$ (Figure 16) shows the potential pathway from the present parameters to reach suitable DO conditions for the settlement and development of slow-growing organisms such as octocorals (gorgonians and soft corals) as well as antipatharians as detected in other areas of El Hierro Island [89].

We suggest that the comparison between habitats growing after submarine eruptions at different ages might be used to infer the rate of biological colonization and the natural ecological succession of habitats after a violent submarine eruption. Previously, a similar approach has been successfully done for understanding geological and biological evolutionary stages in methane seeps displaying different scenarios of rates of fluid venting [79] and hydrodynamics [21]. Therefore, within the Macaronesia volcanic archipelagos, several recent submarine eruptions have taken place in Capelinhos (west Faial Island, Azores) in 1958-59 or south of El Hierro Island (Canary Islands) in 2011-2012 [34]. The recent discovery of soft coral gardens dominated by Alcyonacea in the Azores Archipelago [90] colonizing the volcanic substrate created from the eruption of Capelinhos in 19581-959, opens new studies of succession and survivorship of habitat-forming species in the Macaronesia volcanic areas as they have already been developed in the Hawaiian Islands [91]. 


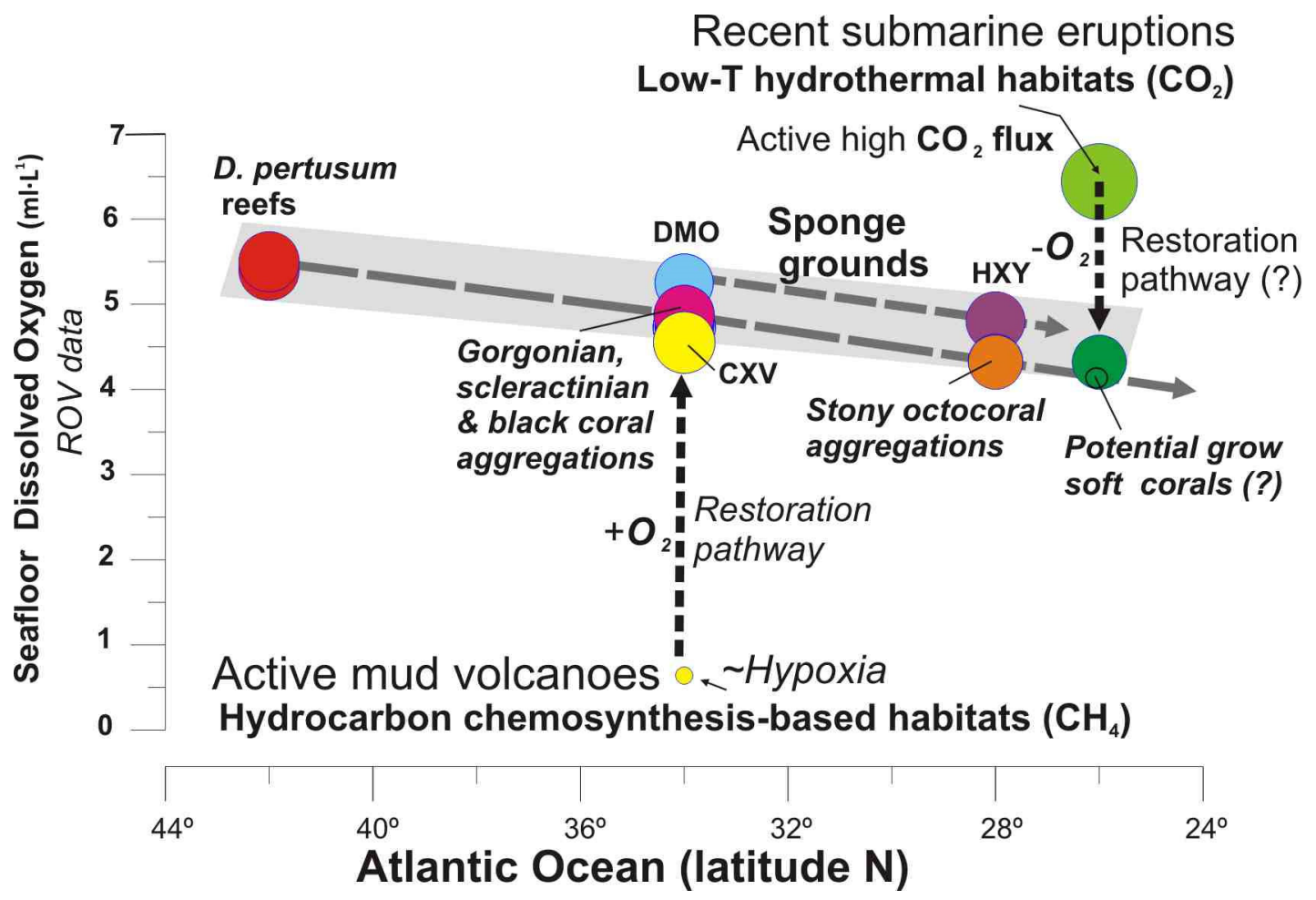

Figure 16. Seafloor dissolved oxygen values vs. latitude for each deep-sea habitat. Grey pattern shows the oxygen threshold for CWC reef and gardens, and deep-sea sponges along the northeast Atlantic Ocean. Dashed black lines show the potential pathways from conditions of cold seeps and recent submarine eruptions to be suitable for non-chemosynthesis-based habitats according the level of dissolved oxygen on the benthic layer. Data are fully listed in Supplementary Table S3.

This fact would support the hypothesis that the type of seabed substrate and the occurrence of fluid flow $\left(\mathrm{CO}_{2}\right.$, methane, sulfide, iron) together with some water mass properties (e.g., current speed, salinity, and temperature) might control the evolution of the type of habitats in such volcanic environments, i.e., (i) soft octocoral gardens developed after recent volcanic eruptions ( $~ 50$ years ago) with latent hydrothermal $\mathrm{CO}_{2}$ degassing and Fe fertilization but causing seabed acidification unsuitable for carbonates; (ii) Coral gardens and sponge aggregations with a wide variety of sessile species (e.g., octocorals, hexactinellid and lithistid sponges, black corals, bamboo corals and large gorgonians) supported by non-degassing volcanic rocks (up thousands of years old) as the submarine ridges of PoL allowing occurrence of carbonate-bearing benthic fauna.

\subsection{Tools for Future Management of Vulnerable Marine Ecosystems}

The integration of high-resolution bathymetry, measurements of in-situ water mass properties, and identification of deep-sea habitats ground truthing by ROV at regional scale represents an important tool for increasing the knowledge and protection of deep-water marine ecosystems, especially those areas with VMEs, affected by the ongoing climate changes and/or contemporary anthropogenic impacts. The future scenario for the impact in deep-sea species and habitats, such as scleractinian reefs, coral gardens or deep-sea sponge aggregations, with potential increases in $\mathrm{CO}_{2}$ and $\mathrm{CH}_{4}$ emissions or rising in the seawater temperature of the oceans at global scale, might be compared with the changes produced, at local scale, by natural emissions of methane in cold seeps or carbon dioxide in recent submarine eruptions.

Otherwise, these integrated studies are also of paramount importance for the efficient management of natural marine resources, such as the ferromanganese crusts bearing seamounts with high contents in $\mathrm{Co}, \mathrm{Ni}$, and other Rare Earth Elements (REE), which are presently targets for mineral exploration in the Area under contracts with the Inter- 
national Seabed Authority (ISA). These seamounts host VMEs, as detected in this and previous studies [92] as well as mineral resources [93] and, thus, spatial management plans are needed to address potential conflicts between deep seabed mining interests and the conservation of the deep-sea biodiversity presented in this study. The same applies for the hydrocarbon-bearing fluid habitats of the studied methane seeps, which are potential target areas for hydrocarbon exploitation in the subsurface and contain singular habitats with endemic species such as the chemosymbiotic bivalves of the GoC.

The five case studies presented here might be considered Ecologically or Biologically Significant Marine Areas (EBSAs) as considered by the United Nations Convention of Biological Diversity (according to different criteria of Annex I, decision IX/20). Unfortunately, significant ecosystem components of those areas (mainly benthic ones) may be threatened by human activities (e.g., fishing activities, hydrocarbon exploitation, or seabed mining), at present or in a near future. Therefore, these selected areas comprising a wide variety of deep-sea habitats in the North Atlantic should be protected and used as pilot areas for further mapping and monitoring of habitats and VMEs, contributing to the environmental management of the North Atlantic Ocean seafloor.

\section{Conclusions}

Five case studies located between 90 and 2500 mbsl depth, along the NE and Central Atlantic Ocean from $23^{\circ} \mathrm{N}$ to $42^{\circ} \mathrm{N}$ latitudes, are presented in this work. These were targeted with MBES mapping, ROV-mounted CTD data of the benthic layer (temperatures, salinity, potential density, dissolved oxygen, potential density, $\mathrm{CO}_{2}, \mathrm{CH}_{4}$ concentration) and identification and sampling of deep-sea habitats. Based on these datasets, we conclude that:

(1) The distribution of deep-sea habitats along the northeastern Atlantic Ocean is somehow influenced by the water mass properties of the benthic layer at basin scale. However, the water mass properties drivers are modulated by the effects, at regional and local scale, of methane seeps or low-temperature hydrothermal fields after submarine eruptions.

(2) Scleractinian reefs and aggregations of gorgonians, antipatharians, and scleractinians are well constrained to thresholds of seafloor temperature $\left(7.31-11.5^{\circ} \mathrm{C}\right)$, salinity (35.13-36.1 psu) and DO $\left(4.325-5.5 \mathrm{~mL} \cdot \mathrm{L}^{-1}\right)$ within a depth range of $800-1400 \mathrm{~m}$. These habitats appear distributed into three levels according to their values of temperature, salinity, potential density and DO: (i) Desmophyllum pertusum reefs with the higher values in temperature, salinity and DO values; (ii) Aggregations of gorgonians, scleractinians, and antipatharians with intermediate levels, and (iii) Aggregations of stony octocorals with the lower values in temperature, salinity and DO.

(3) The reef-forming D. pertusum identified in the Galicia Bank (NE Atlantic) matches the temperatures, salinity, and potential density values of other scleractinian reefs along the NE Atlantic margins as related to cold North Atlantic waters. However, our data show that other deep-sea corals living along the southern NE Atlantic between the NW African margin and Canary Islands are influenced by the mixing between the intermediate waters MOW and AAIW. This fact highlights the importance of the turbulent interaction between flows of intermediate water masses for deep-sea coral growth along the NE Atlantic Ocean.

(4) Based on these new data, we suggest that the limit between northward intrusions of the AAIW mass waters and the MOW outflow could represent a biogeographical boundary between habitats dominated by colonial scleractinians and with those dominated by gorgonians and stony octocorals. South of $35^{\circ} \mathrm{N}$, deep-sea corals are represented by aggregations of stony octocorals (Corallium tricolor and C. niobe), antipatharians, and gorgonians instead of living scleractinian reefs and banks of the NE Atlantic. Along the NW Africa margin, giant coral ridges and mounds of mostly dead scleractinians (D. pertusum and M. oculata) has been reported off Morocco and the Mauritanian coast along the shelf break. This is an example of the dramatic loss of deep-sea scleractinian reefs along the northeast Atlantic Ocean since the last glacial. 
(5) The co-occurrence of deep-sea coral and sponge habitats and chemosynthesis-based habitats was detected in methane seeps of the Gulf of Cádiz. Thus, extensive beds of living deep-sea mussels Bathymodiolus mauritanicus and other chemosymbiotic bivalves around focused bubbling $\mathrm{CH}_{4}$ vents are placed close to aggregations of sponges, scleractinians, gorgonians, and antipatharians colonizing newly formed MDACs carbonates. Colonies of Sibloginid sp. tubeworms play an important role in the connectivity between seeps and some of these suspension feeders by generating pavement patches of MDACs and allowing them to be isolated from the acidic seafloor [69].

(6) Our data support that some deep-sea habitats can be very sensitive to local variations in dissolved oxygen (DO) concentrations within the benthic layer.

Supplementary Materials: The following are available online at https:/ /www.mdpi.com/article/10 $.3390 /$ oceans2020021/s1. Table S1: Cruise details, MBEs system and configurations, oceanographic data and sampling methods; Table S2: Seabed substrate, morphology, oceanographic variables, VME Indicator Taxa and seafloor micro-morphologies and habitat types; Table S3: ROV-mounted CTD mass water data.

Author Contributions: L.S. was the chief scientist of the SUBVENT-2 cruise and led the overall organization of the text. J.L.R. directed the collection of biological observations and the biological text of the manuscript. O.S.-G. contribute to the overall text of the manuscript and biological descriptions. P.M. lead the ROV "Luso" operations. B.R.-T. directed the microbiological analyses. D.P., R.L. and L.M.F.-S. processed bathymetry, provide multibeam maps and contributed to geomorphological description of the manuscript. T.M. and M.d.C.F.-P. contributed to the geology of the manuscript. F.J.G. and E.M. contributed to the petrological parts of the manuscript. E.L.-P. and E.S. contribute to physic-chemical data. J.T.V. was the chief scientist of the DRAGO511 cruise. All authors contributed to the writing of a draft of the manuscript. All authors have read and agreed to the published version of the manuscript.

Funding: Support for this work comes from the EXPLOSEA (CTM201675947-R), SUBVENT (CGL201239524-CO2), and EXARCAN (CTM2010-09496-E) projects funded by the Ministerio de Ciencia e Innovación of Spain. This study also benefits from the Atlantic Seabed Mapping International Working Group (ASMIWG) as part of the Atlantic Ocean Research Alliance Coordination and Support Action (AORA-CSA). This study is also a contribution to the EMODNET-Geology project (EASME/EMFF/2018/1.3.1.8-Lot 1/SI2.811048) and the European project H2020 GeoERA-MINDeSEA (Grant Agreement No. 731166, project GeoE.171.001).

Data Availability Statement: The data presented in this study are available on request from the corresponding author.

Acknowledgments: The authors thank captains, crew and ship parties of all scientific cruises aboard R/V "Hespérides", "Sarmiento de Gamboa" and "Miguel Oliver". Special thanks to the ROV "Luso"pilots team Antonio Calado, Andreia Afonso, Miguel Souto and Renato Bettencourt that have been the basis for this paper. Special thanks to the personnel of the Instituto Hidrográfico de la Marina (IHM) for their cooperation in the processing of multibeam bathymetry data.

Conflicts of Interest: The authors declare no conflict of interest.

\section{References}

1. Da Ros, Z.; Dell'Anno, A.; Morato, T.; Sweetman, A.K.; Carreiro-Silva, M.; Smith, C.J.; Papadopoulou, N.; Corinaldesi, C.; Bianchelli, S.; Gambi, C.; et al. The deep sea: The new frontier for ecological restoration. Mar. Policy 2019, 108, 103642. [CrossRef]

2. Mayer, L.; Jakobsson, M.; Allen, G.; Dorschel, B.; Falconer, R.; Ferrini, V.; Lamarche, G.; Snaith, H.; Weatherall, P. The Nippon Foundation-GEBCO seabed 2030 project: The quest to see the world's oceans completely mapped by 2030. Geosciences 2018, 8, 63. [CrossRef]

3. Harris, P.; Baker, E.K. Seafloor Geomorphology as Benthic Habitat: GeoHab Atlas of Seafloor Geomorphic Features and Benthic Habitats; Elsevier: Amsterdam, The Netherlands, 2012; p. 936.

4. International Hydrographic Organization; Intergovernmental Oceanographic Commission. Standardization of Undersea Feature Names-Guidelines, Proposal Form, Terminology; Edition 4.1.0 English/Spanish Version; IHO-IOC Publication B-6; Monaco International Hydrographic Bureau: Monaco, 2017; p. 23. 
5. Ercilla, G.; Casas, D.; Vázquez, J.T.; Iglesias, J.; Somoza, L.; Juan, C.; Medialdea, T.; León, R.; Estrada, F.; García-Gil, S.; et al. Imaging the recent sediment dynamics of the Galicia Bank region (Atlantic, NW Iberian Peninsula). Mar. Geophys. Res. 2011, 32, 99-126. [CrossRef]

6. Serrano, A.; González-Irusta, J.M.; Punzón, A.; García-Alegre, A.; Lourido, A.; Ríos, P.; Blanco, M.; Gómez-Ballesteros, M.; Druet, M.; Cristobo, J.; et al. Deep-sea benthic habitats modeling and mapping in a NE Atlantic seamount (Galicia Bank). Deep-Sea Res. Part I Oceanogr. Res. Pap. 2017, 126, 115-127. [CrossRef]

7. González, F.J.; Somoza, L.; Hein, J.R.; Medialdea, T.; León, R.; Urgorri, V.; Reyes, J.; Martín-Rubí, J.A. Phosphorites, Co-rich Mn nodules, and Fe-Mn crusts from Galicia Bank, NE Atlantic: Reflections of Cenozoic tectonics and paleoceanography. Geochem. Geophys. Geosyst. 2016, 17, 346-374. [CrossRef]

8. Iorga, M.; Lozier, M. Signatures of the Mediterranean outflow from a North Atlantic climatology: 2. Diagnostic velocity fields. J. Geophys. Res. 1999, 104, 26011-26029. [CrossRef]

9. Ambar, I.; Howe, M.R. Observations of the Mediterranean outflow-I mixing in the Mediterranean outflow. Deep Sea Res. 1979, 26, 535-554. [CrossRef]

10. Machín, F.; Pelegrí, J.L. Northward penetration of Antarcticintermediate water off Northwest Africa. J. Phys. Oceanogr. 2009, 39, 512-535. [CrossRef]

11. Prieto, E.; González-Pola, C.; Lavín, A.; Sanchez, R.F.; Ruiz-Villarreal, M. Seasonality of intermediate waters hydrography west of the Iberian Peninsula from an 8 yr semiannual time series of an oceanographic section. Ocean Sci. 2013, 9, 411-429. [CrossRef]

12. Puerta, P.; Johnson, C.; Carreiro-Silva, M.; Henry, L.A.; Kenchington, E.; Morato, T.; Kazanidis, G.; Rueda, J.L.; Urra, J.; Ross, S.; et al. Influence of Water Masses on the Biodiversity and Biogeography of Deep-Sea Benthic Ecosystems in the North Atlantic. Front. Mar. Sci. 2020, 7, 239. [CrossRef]

13. Gardner, J.M. Mud volcanoes on the Moroccan Margin. EOS Trans. AGU 1999, 80, 483.

14. Ivanov, M.K.; Woodside, J.M.; Kenyon, N.H.; TTR Shipboard Party. Principal Scientific Results of the TTR. First Decade. In Geological Processes on Deep-Water European Margins, Proceedings of the International Conference and Ninth Post-Cruise Meeting of the Training-Through-Research Programme, Moscow-Mozhenka, Russia, 28 January-2 February 2001; Akhmanov, G., Suzyumov, A., Eds.; Intergovernmental Oceanographic Commission: Paris, France, 2001.

15. Somoza, L.; Gardner, J.M.; Diaz-del-Rio, V.; Vazquez, T.; Pinheiro, L.; Hernández-Molina, F.J.; TASYO/ANASTASYA Shipboard Scientific Parties. Numerous methane gas related seafloor structures identified in the Gulf of Cádiz. EOS Trans. AGU 2002, 83, 541-547. [CrossRef]

16. Somoza, L.; Díaz-del-Río, V.; León, R.; Ivanov, M.; Fernández-Puga, M.C.; Gardner, J.M.; Hernández-Molina, F.J.; Pinheiro, L.M.; Rodero, J.; Lobato, A.; et al. Seabed morphology and hydrocarbon seepage in the Gulf of Cádiz mud volcano area: Acoustic imagery, multibeam and ultrahigh resolution seismic data. Mar. Geol. 2003, 195, 153-176. [CrossRef]

17. Pinheiro, L.M.; Ivanov, M.K.; Sautkin, A.; Akhmanov, G.; Magalhães, V.H.; Volkonskaya, A.; Monteiro, J.H.; Somoza, L.; Gardner, J.; Hamouni, N.; et al. Mud volcanism in the Gulf of Cádiz: Results from the TTR-10 cruise. Mar. Geol. 2003, 195, 131-151. [CrossRef]

18. Van Rensbergen, P.; Depreiter, D.; Pannemans, B.; Moerkerke, G.; Van Rooij, D.; Marsset, B.; Akhmanov, G.; Blinova, V.; Ivanov, M.; Rachidi, M.; et al. The Arraiche mud volcano field at the Moroccan Atlantic slope, Gulf of Cádiz. Mar. Geol. 2005, $219,1-17$. [CrossRef]

19. Medialdea, T.; Somoza, L.; Pinheiro, L.M.; Fernández-Puga, M.C.; Vázquez, J.T.; León, R.; Ivanov, M.K.; Magalhães, V.H.; Díaz-del-Río, V.; Vegas, R. Tectonics and mud volcano development in the Gulf of Cádiz. Mar. Geol. 2009, 261, 48-63. [CrossRef]

20. León, R.; Somoza, L.; Medialdea, T.; Vázquez, J.T.; González, F.J.; López-González, N.; Casas, D.; Mata, M.P.; Fernández-Puga, M.C.; Giménez-Moreno, C.J.; et al. New discoveries of mud volcanoes on the Moroccan Atlantic continental margin (Gulf of Cádiz): Morpho-structural characterization. Geo Mar. Lett. 2012, 32, 473-488. [CrossRef]

21. Palomino, D.; López-González, N.; Vázquez, J.T.; Fernández-Salas, L.M.; Rueda, J.L.; Sanchez-Leal, R.; Díaz-del-Río, V. Multidisciplinary study of mud volcanoes and diapirs and their relationship to seepages and bottom currents in the Gulf of Cádiz continental slope (northeastern sector). Mar. Geol. 2016, 378, 196-212. [CrossRef]

22. Hensen, C.; Nuzzo, M.; Hornibrook, E.; Pinheiro, L.M.; Bock, B.; Magalhães, V.H.; Brückmann, W. Sources of mud volcano fluids in the Gulf of Cádiz-indications for hydrothermal imprint. Geochim. Cosmochim. Acta 2007, 71, 1232-1248. [CrossRef]

23. Medialdea, T.; Vegas, R.; Somoza, L.; Vázquez, J.T.; Maldonado, A.; Díaz-del-Río, V.; Maestro, A.; Córdoba, D.; Fernández-Puga, M.C. Structure and evolution of the "Olistostrome" complex of the Gibraltar Arc in the Gulf of Cádiz (eastern Central Atlantic): Evidence from two long seismic cross-sections. Mar. Geol. 2004, 209, 173-198. [CrossRef]

24. Toyos, M.H.; Medialdea, T.; León, R.; Somoza, L.; González, F.J.; Meléndez, N. Evidence of episodic long-lived eruptions in the Yuma, Ginsburg, Jesús Baraza and Tasyo mud volcanoes, Gulf of Cádiz. Geo-Mar. Lett. 2016. [CrossRef]

25. Díaz-del-Río, V.; Somoza, L.; Martínez-Frías, J.; Mata, M.P.; Delgado, A.; Hernandez-Molina, F.J.; Lunar, R.; Martín-Rubí, J.A.; Maestro, A.; Fernández-Puga, M.C.; et al. Vast fields of hydrocarbon-derived carbonate chimneys related to the accretionary wedge/olistostrome of the Gulf of Cádiz. Mar. Geol. 2003, 195, 177-200. [CrossRef]

26. Magalhães, V.H.; Pinheiro, L.M.; Ivanov, M.K.; Kozlova, E.; Blinova, V.; Kolganova, J.; Vasconcelos, C.; McKenzie, J.A.; Bernasconi, S.M.; Kopf, A.J.; et al. Formation processes of methane-derived authigenic carbonates from the Gulf of Cádiz. Sed. Geol. 2012, 243-244, 155-168. [CrossRef] 
27. Boetius, A.; Ravenschlag, K.; Schubert, C.J.; Rickert, D.; Widdel, F.; Gieseke, A.; Amann, R.; Jørgensen, B.B.; Witte, U.; Pfannkuche, O. A marine microbial consortium apparently mediating anaerobic oxidation of methane. Nature 2000, 407, 623-626. [CrossRef] [PubMed]

28. González, F.J.; Somoza, L.; Lunar, R.; Martínez-Frías, J.; Martín-Rubí, J.M.; Torres, T.; Ortiz, J.E.; Díaz-del-Río, V.; Pinheiro, L.M.; Magalhães, V.H. Hydrocarbon-derived ferromanganese nodules in carbonate-mud mounds from the Gulf of Cadiz: Mud-breccia sediments and clasts as nucleation sites. Mar. Geol. 2009, 261, 64-81. [CrossRef]

29. Ryan, W.F.B.; Carbotte, S.M.; Coplan, J.O.; O’Hara, S.; Melkonian, A.; Arko, R.; Weissel, R.A.; Ferrini, V.; Goodwillie, A.; Nitsche, F.; et al. Global multi-resolution topography synthesis. Geochem. Geophys. Geosyst. 2009, 10, 1525-2027. [CrossRef]

30. Acosta, J.; Uchupi, E.; Muñoz, A.; Herranz, P.; Palomo, C.; Ballesteros, M. ZEE Working Group Salt Diapirs, Salt Brine Seeps, Pockmarks and Surficial Sediment Creep and Slides in the Canary Channel off NW Africa. Mar. Geophys. Res. 2003, $24,41-57$. [CrossRef]

31. Vázquez, J.T.; Palomino, D.; Fernández-Puga, M.C.; Fernández-Salas, L.M.; Fraile-Nuez, E.; Medialdea, T.; Sánchez-Guillamón, O.; Somoza, L.; SUBVENT Team. Seafloor geomorphology of the Passage of Lanzarote (West Africa Margin): Influences of the oceanographic processes. In 2nd Deep-Water Circulation Congress; Van Rooij, D., Rüggeberg, A., Eds.; VLIZ Special Publication: Ghent, Belgium, 2014; pp. 125-126. [CrossRef]

32. Hernández-Guerra, A.; Fraile-Nuez, E.; Borges, R.; López-Laatzen, F.; Vélez-Belchı́, P.; Parrilla, G.; Müller, T.J. Transport variability in the Lanzarote passage (eastern boundary current of the North Atlantic subtropical Gyre). Deep Sea Res. Part I 2003, 50, 189-200. [CrossRef]

33. Machín, F.; Hernández-Guerra, A.; Pelegrí, J.L. Mass fluxes in the Canary Basin. Prog. Oceanogr. 2006, 70, 416-447. [CrossRef]

34. Somoza, L.; González, F.J.; Barker, S.J.; Madureira, P.; Medialdea, T.; de Ignacio, C.; Lourenço, N.; León, R.; Vázquez, J.T.; Palomino, D. Evolution of submarine eruptive activity during the 2011 El Hierro event as documented by hydroacoustic images and remotely operated vehicle observations. Geochem. Geophys. Geosyst. 2017, 18. [CrossRef]

35. Fraile-Nuez, E.; González-Dávila, M.; Santana-Casiano, J.M.; Arístegui, J.; Alonso-González, I.J.; Hernández-León, S.; Blanco, M.J.; Rodríguez-Santana, A.; Hernández-Guerra, A.; Gelado-Caballero, M.D.; et al. The submarine volcano eruption at the island of El Hierro: Physical-chemical perturbation and biological response. Sci. Rep. 2012, 2, 486. [CrossRef]

36. Santana-Casiano, J.M.; González-Dávila, M.; Fraile-Nuez, E.; de Armas, D.; González, A.G.; Domínguez-Yanes, A.; Escánez, J. The natural ocean acidification and fertilization event caused by the submarine eruption of El Hierro. Sci. Rep. 2013, 3, 1140. [CrossRef]

37. Palomino, D.; Vázquez, J.T.; Somoza, L.; León, R.; López-González, N.; Medialdea, T.; Fernández-Salas, L.M.; González, F.J.; Rengel, J.A. Geomorphological features in the southern Canary Island Volcanic Province: The importance of volcanic processes and massive slope instabilities associated with seamounts. Geomorphology 2016, 255, 125-139. [CrossRef]

38. Bogaard, P. The origin of the Canary Island Seamount Province-New ages of old seamounts. Sci. Rep. 2013, 3, 1-7.

39. Marino, E.; González, F.J.; Somoza, L.; Lunar, R.; Ortega, L.; Vázquez, J.T.; Reyes, J.; Bellido, E. Strategic and rare elements in Cretaceous-Cenozoic cobalt-rich ferromanganese crusts from seamounts in the Canary Island Seamount Province (northeastern tropical Atlantic). Ore Geol. Rev. 2017, 87, 41-61. [CrossRef]

40. Marino, E.; González, F.J.; Lunar, R.; Reyes, J.; Medialdea, T.; Castillo-Carrión, M.; Bellido, E.; Somoza, L. High-Resolution Analysis of Critical Minerals and Elements in Fe-Mn Crusts from the Canary Island Seamount Province (Atlantic Ocean). Minerals 2018, 8, 285. [CrossRef]

41. Marino, E.; González, F.J.; Kuhn, T.; Madureira, P.; Wegorzewski, A.V.; Mirao, J.; Medialdea, T.; Oeser, M.; Miguel, C.; Reyes, J.; et al. Hydrogenetic, diagenetic and hydrothermal processes forming ferromanganese crusts in the Canary Island Seamounts and their influence in the metal recovery rate with hydrometallurgical methods. Minerals 2019, 9, 439. [CrossRef]

42. Brandt, P.; Hormann, V.; Körtzinger, A.; Visbeck, M.; Krahmann, G.; Stramma, L.; Lumpkin, R.; Schmid, C. Changes in the ventilation of the oxygen minimum zone of the tropical North Atlantic. J. Phys. Oceanogr. 2010, 40, 1784-1801. [CrossRef]

43. Somoza, L.; Vázquez, J.T.; Campos, A.; Afonso, A.; Calado, A.; Fernández-Puga, M.C.; González, F.J.; Fernández-Salas, L.M.; Ferreira, M.; Sanchez-Guillamón, O.; et al. Informe Científico-Técnico Campaña SUBVENT-2, 2014, p. 43. Available online: http://info.igme.es/SidPDF/166000/941/166941_0000001.pdf (accessed on 1 December 2020).

44. Boyer, T.P.; Baranova, O.K.; Coleman, C.; García, H.E.; Grodsky, A.; Locarnini, R.A.; Mishonov, A.V.; Paver, C.R.; Reagan, J.R.; Seidov, D.; et al. World Ocean Database 2018. Available online: https:/ /www.ncei.noaa.gov/sites/default/files/2020-04/wod_ intro_0.pdf (accessed on 1 December 2020).

45. Schlitzer, R. Ocean Data View 2017. Available online: http:/ / odv.awi.de (accessed on 1 December 2020).

46. Somoza, L.; Ercilla, G.; Urgorri, V.; León, R.; Medialdea, T.; Paredes, M.; González, F.J.; Nombela, M.A. Detection and mapping of cold-water coral mounds and living Lophelia reefs in the Galicia Bank, Atlantic NW Iberia margin. Mar. Geol. 2014, 349, 73-90. [CrossRef]

47. Urgorri, V.; Troncoso, J.S. A second record of Laevipilinarolani Warén\&Bouchet, 1990 (Mollusca: Monoplacophora) from the Northwestof Spain. J. Molluscan Stud. 1994, 60, 157-163.

48. Vázquez, J.T.; Ercilla, G.; Somoza, L.; Palomino, D.; Alonso, B.; Casas, D.; Estrada, F.; Fernández-Puga, M.C.; Fernández-Salas, L.M.; León, R.; et al. Giant depressions on Atlantic continental margins: Relationship with diapirs. In Book of Proceedings of the IX Symposium MIA2018; Cunha, P.P., Dias, J., Veríssimo, H., Duarte, L.V., Dinis, P., Lopes, F.C., Bessa, A.F., Carmo, J.A., Eds.; Universidade de Coimbra: Coimbra, Portugal, 2018; pp. 251-252. 
49. Rivera, J.; Lastras, G.; Canals, M.; Acosta, J.; Arrese, B.; Hermida, N.; Micallef, A.; Tello, O.; Amblas, D. Construction of an oceanic island: Insights from the El Hierro (Canary Islands) 2011-2012 submarine volcanic eruption. Geology 2013, 41, 355-358. [CrossRef]

50. González, F.J.; Rincón-Tomás, B.; Somoza, L.; Santofimia, E.; Medialdea, T.; Madureira, P.; López-Pamo, E.; Hein, J.R.; Marino, E.; de Ignacio, C.; et al. Low-temperature, shallow-water hydrothermal vent mineralization following the recent submarine eruption of Tagoro volcano (El Hierro, Canary Islands). Mar. Geol. 2020, 430, 106333. [CrossRef]

51. Dando, P.R.; Hovland, M. Environmental effects of submarine seeping natural gas. Cont. Shelf Res. 1992, 12, 1197-1207. [CrossRef]

52. Judd, A.; Hovland, M. Seabed Fluid Flow. Impact on Geology, Biology, and the Marine Environment; Cambridge University Press: Cambridge, UK, 2007.

53. Levin, L.A.; Baco, A.R.; Bowden, D.A.; Colaco, A.; Cordes, E.E.; Cunha, M.R.; Demopoulos, A.W.J.; Gobin, J.; Grupe, B.M.; Le, J.; et al. Hydrothermal vents and methane seeps: Rethinking the sphere of influence. Front. Mar. Sci. 2016, 3, 72. [CrossRef]

54. Rueda, J.L.; González-García, E.; Krutzky, C.; López-Rodríguez, F.J.; Bruque-Carmona, G.; López-González, N.; Palomino, D.; Sánchez-Leal, R.F.; Vázquez, J.T.; Fernández-Salas, L.M.; et al. From chemosynthesis-based communities to cold-water corals: Vulnerable deep-sea habitats of the Gulf of Cádiz. Mar. Biodivers. 2016, 46, 473-482. [CrossRef]

55. Lozano, P.; Rueda, J.L.; Gallardo-Núñez, M.; Urra, C.F.J.; Vila, Y.; López-González, N.; Palomino, D.; Sánchez-Guillamón, O.; Vázquez, J.T.; Fernández-Salas, L.M. Chapter 52-Habitat distribution and associated biota in different geomorphic features within a fluid venting area of the Gulf of Cádiz (Southwestern Iberian Peninsula, Northeast Atlantic Ocean). In Seafloor Geomorphology as Benthic Habitat, 2nd ed.; Harris, P., Baker, E., Eds.; Elsevier: Amsterdam, The Netherlands, 2020 ; pp. 847-861.

56. Yasuhara, M.; Danovaro, R. Temperature impacts on deep-sea biodiversity. Biol. Rev. 2014, 91, 275-287. [CrossRef]

57. Freiwald, A.; Roberts, J.M. Cold-Water Corals and Ecosystems; Springer: Berlin/Heidelberg, Germany, 2005.

58. Buhl-Mortensen, L.; Olafsdottir, S.H.; Buhl-Mortensen, P.; Burgos, J.M.; Ragnarsson, S.A. Distribution of nine cold-water coral species (Scleractinia and Gorgonacea) in the cold temperate North Atlantic: Effects of bathymetry and hydrography. Hydrobiologia 2015, 759, 39-61. [CrossRef]

59. Ramalho, L.V.; López-Fé, C.M.; Mateo-Rodríguez, A.; Rueda, J.L. Bryozoa from Deep-sea habitats of the northern Gulf of Cádiz (Northeastern Atlantic). Zootaxa 2020, 4768, 451-478. [CrossRef]

60. Sitjà, C.; Maldonado, M.; Farias, C.; Rueda, J.L. Export of bathyal benthos to the Atlantic through the Mediterranean outflow: Sponges from the mud volcanoes of the Gulf of Cadiz as a case study. Deep Sea Res. Part I 2020, 163, 103326. [CrossRef]

61. Rodrigues, C.F.; Hilário, A.; Cunha, M.R. Chemosymbiotic species from the Gulf of Cadiz (NE Atlantic): Distribution, life styles and nutritional patterns. Biogeosciences 2013, 10, 2569. [CrossRef]

62. Dullo, W.C.; Flögel, S.; Rüggerberg, A. Cold-water coral growth in relation to the hydrography of the Celtic and Nordic European continental margin. Mar. Ecol. Prog. Series 2008, 371, 165-176. [CrossRef]

63. Huvenne, V.A.; Masson, D.G.; Wheeler, A.J. Sediment dynamics of a sandy contourite: The sedimentary context of the Darwin cold-water coral mounds, Northern Rockall Trough. Int. J. Earth Sci. 2009, 98, 865-884. [CrossRef]

64. Xavier, J.; van Soest, R. Demosponge fauna of Ormonde and Gettysburg Seamounts (Gorringe Bank, north-east Atlantic): Diversity and zoogeographical affinities. JMBA J. Mar. Biol. Assoc. UK 2007, 87, 1643-1654. [CrossRef]

65. Watling, L.; Guinotte, J.; Clark, M.R.; Smith, C.R. A proposed biogeography of the deep ocean floor. Prog. Oceanogr. 2013, 111, 91-112. [CrossRef]

66. Ceramicola, S.; Dupré, S.; Somoza, L.; Woodside, J. Cold seep systems. In Submarine Geomorphology; Micallef, A., Krastel, S., Savini, A., Eds.; Springer International Publishing: Cham, Switzerland, 2018; pp. 367-388.

67. Rincón-Tomás, B.; González, F.J.; Somoza, L.; Sauter, K.; Madureira, P.; Medialdea, T.; Carlsson, J.; Reitner, J.; Hoppert, M. Siboglinidae Tubes as an Additional Niche for Microbial Communities in the Gulf of Cádiz-A Microscopical Appraisal. Microorganisms 2020, 8, 367. [CrossRef]

68. Demopoulos, A.W.; Bourque, J.R.; Frometa, J. Biodiversity and community composition of sediment macrofauna associated with deep-sea Lophelia pertusa habitats in the Gulf of Mexico. Deep Sea Res. Part I 2014, 93, 91-103. [CrossRef]

69. Rincón-Tomás, B.; Duda, J.P.; Somoza, L.; González, F.J.; Schneider, D.; Medialdea, T.; Reitner, J. Cold-water corals and hydrocarbon-rich seepage in Pompeia Province (Gulf of Cádiz)-Living on the edge. Biogeosciences 2019, 16, 1607-1627. [CrossRef]

70. Roque, D.; Parras-Berrocal, I.; Bruno Mejías, M.; Sanchez Leal, R.F.; Hernández-Molina, F.J. Seasonal variability of intermediate water masses in the Gulf of Cádiz: Implications of the Antarctic and subarctic seesaw. Ocean. Sci. 2019, 15, 1381-1397. [CrossRef]

71. Foubert, A.; Depreiter, D.; Beck, T.; Maignien, L.; Pannemans, B.; Frank, N.; Blamart, D.; Henriet, J.-P. Carbonate mounds in a mud volcano province off north-west Morocco: Key to processes and controls. Mar. Geol. 2008, 248, 74-96. [CrossRef]

72. Wienberg, C.; Hebbeln, D.; Fink, H.G.; Mienis, F.; Dorschel, B.; Vertino, A.; López Correa, M.; Freiwald, A. Scleractinian cold-water corals in the Gulf of Cádiz -first clues about their spatial and temporal distribution. Deep-Sea Res. 2009, 56, 1873-1893. [CrossRef]

73. Hebbeln, D.; Van Rooij, D.; Wienberg, C. Good neighbours shaped by vigorous currents: Cold-water coral mounds and contourites in the North Atlantic. Mar. Geol. 2016, 378, 171-185. [CrossRef]

74. Wienberg, C.; Titschack, J.; Freiwald, A.; Frank, N.; Lundälv, T.; Taviani, M.; Beuck, L.; Schröder-Ritzrau, A.; Krengel, T.; Hebbeln, D. The giant Mauritanian cold-water coral mound province: Oxygen control on coral mound formation. Quat. Sci. Rev. 2018, 185, 135-152. [CrossRef]

75. De la Fuente, M.; Skinner, L.; Ercilla, G.; d’Acremont, E.; Somoza, L.; González, F.J.; Lo Iacono, C.; Corbera, G.; Pena, L.D.; Sadekov, A.; et al. Inferring deglacial ventilation ages in Western Mediterranean waters using cold-water corals. In EGU General Assembly Conference Abstracts; EGU2020-20171; EGU: Viena, Austria, 2020. [CrossRef] 
76. Hinrichs, K.U.; Boetius, A. The anaerobic oxidation of methane: New insights inmicrobial ecology and biogeochemistry. In Ocean Margin Systems; Wefer, G., Billett, D., Hebbeln, D., Jørgensen, B.B., Schlüter, M., van Weering, T.C.E., Eds.; Springer: Berlin/Heidelberg, Germany, 2002; pp. 457-477.

77. Van Rooij, D.; Blamart, D.; De Mol, L.; Mienis, F.; Pirlet, H.; Wehrmann, L.M.; Barbieri, R.; Maignien, L.; Templer, S.P.; de Haas, H.; et al. Cold-water coral mounds on the Pen Duick Escarpment, Gulf of Cádiz: The MiCROSYSTEMS project approach. Mar. Geol. 2011, 282, 102-117. [CrossRef]

78. Hovland, M. Do carbonate reefs form due to fluid seepage? Terra Nova 1990, 2, 8-18. [CrossRef]

79. León, R.; Somoza, L.; Medialdea, T.; González, F.J.; Díaz-del-Río, V.; Fernández-Puga, M.; Maestro, A.; Mata, M.P. Sea-floor features related to hydrocarbon seeps in deepwater carbonate-mud mounds of the Gulf of Cádiz: From mud flows to carbonate precipitates. Geo-Mar. Lett. 2007, 27, 237-247. [CrossRef]

80. Becker, E.L.; Cordes, E.E.; Macko, S.A.; Fisher, C.R. Importance of seep primary production to Lophelia pertusa and associated fauna in the Gulf of Mexico. Deep Sea Res. Part I 2009, 56, 786-800. [CrossRef]

81. Demopoulos, A. Biodiversity, biogeography, and connectivity of seeps and cold-water coral communities in the Gulf of Mexico. Beyond Horiz. 2011, 11, 37.

82. Liebetrau, V.; Eisenhauer, A.; Linke, P. Cold seep carbonates and associated cold-water corals at the Hikurangi Margin, New Zealand: New insights into fluid pathways, growth structures and geochronology. Mar. Geol. 2010, 272, 307-318. [CrossRef]

83. Gomes-Sumida, P.Y.; Yoshinaga, M.Y.; Madureira, L.A.S.-P.; Hovland, M. Seabed pockmarks associated with deep water corals off SE Brazilian continental slope, Santos Basin. Mar. Geol. 2004, 207, 159-167. [CrossRef]

84. Henriet, J.P.; Van Rooij, D.; Huvenne, V.; De Mol, B.; Guidard, S. Mounds and sediment drift in the Porcupine Basin, west of Ireland. In European Continental Margin Sedimentary Processes: An Atlas of Side-Scan Sonar and Seismic Images; Mienert, J., Weaver, P., Eds.; Springer: Berlin/Heidelberg, Germany, 2003; pp. 217-220.

85. Bourque, J.R.; Robertson, C.M.; Brooke, S.; Demopoulos, A.W. Macrofaunal communities associated with chemosynthetic habitats from the US Atlantic margin: A comparison among depth and habitat types. Deep Sea Res. Part II 2017, 137, 42-55. [CrossRef]

86. Prouty, N.G.; Sahy, D.; Ruppel, C.D.; Roark, E.B.; Condon, D.; Brooke, S.; Ross, S.W.; Demopoulos, A.W.J. Insights into methane dynamics from analysis of authigenic carbonates and chemosynthetic mussels at newly-discovered Atlantic Margin seeps. Earth Planet. Sci. Lett. 2016, 449, 332-344. [CrossRef]

87. Alt, J.C. Hydrothermal fluxes at mid-ocean ridges and on ridge flanks. Geochemistry 2003, 335, 853-864. [CrossRef]

88. Medialdea, T.; Somoza, L.; González, F.J.; Vázquez, J.T.; de Ignacio, C.; Sumino, H.; Sánchez-Guillamón, O.; Orihashi, Y.; León, R.; Palomino, D. Evidence of a modern deep water magmatic hydrothermal system in the Canary Basin (eastern central Atlantic Ocean). Geochem. Geophys. Geosyst. 2017, 18. [CrossRef]

89. Sotomayor-García, A.; Rueda, J.L.; Sánchez-Guillamón, O.; Urra, J.; Vázquez, J.T.; Palomino, D.; Fernández-Salas, L.M.; LópezGonzález, N.; González-Porto, M.; Santana-Casiano, J.M.; et al. First Macro-Colonizers and Survivors Around Tagoro Submarine Volcano, Canary Islands, Spain. Geosciences 2019, 9, 52. [CrossRef]

90. Somoza, L.; Medialdea, T.; González, F.J.; Calado, A.; Afonso, A.; Albuquerque, M.; Asensio-Ramos, M.; Bettencourt, R.; Blasco, I.; Candón, J.A.; et al. Multidisciplinary Scientific Cruise to the Northern Mid-Atlantic Ridge and Azores Archipelago. Front. Mar. Sci. 2020. [CrossRef]

91. Putts, M.R.; Parrish, F.A.; Trusdell, F.A.; Kahng, S.E. Structure and development on Hawaiian Deep-water coral communities on Mauna Loa lava flows. Mar. Ecol. Prog. Ser. 2019, 630, 69-82. [CrossRef]

92. Ramiro-Sánchez, B.; González-Irusta, J.M.; Henry, L.A.; Cleland, J.; Yeo, I.; Xavier, J.R.; Carreiro-Silva, M.; Sampaio, I.; Spearman, J.; Victorero, L.; et al. Characterization and mapping of a deep-sea sponge ground on the Tropic Seamount (Northeast Tropical Atlantic): Implications for Spatial Management in the High Seas. Front. Mar. Sci. 2019, 6, 278. [CrossRef]

93. Hein, J.R.; Mizell, K.; Koschinsky, A.; Conrad, T.A. Deep-ocean mineral deposits as a source of critical metals for high- and green-technology applications: Comparison with land-based resources. Ore Geol. Rev. 2013, 51, 1-14. [CrossRef] 